NBER WORKING PAPER SERIES

\title{
THE CROSS-SECTION OF CURRENCY RISK PREMIA AND US CONSUMPTION GROWTH RISK
}

\author{
Hanno Lustig \\ Adrien Verdelhan \\ Working Paper 11104 \\ http://www.nber.org/papers/w11104
NATIONAL BUREAU OF ECONOMIC RESEARCH
1050 Massachusetts Avenue
Cambridge, MA 02138
February 2005

First version November 2003. The authors especially thank Andy Atkeson, John Cochrane, Lars Hansen and Anil Kashyap for detailed comments, as well as Ravi Bansal, Hal Cole, Fran»cois Gourio, John Heaton, Lee Ohanian, Fabrizio Perri, Stijn Van Nieuwerburgh and the participants of the GSB macro lunch, the macro seminar at the University of Maryland, UCLA, UCSD, the Fuqua School of Business at Duke, Stanford University, the 2004 Annual Meeting of the Econometric Society, and the 2004 Cleveland Fed conference on International Economics, for helpful suggestions. Dennis Quinn and Carmen Reinhardt were kind enough to share their data with us. Stijn Van Nieuwerburgh shared his matlab code and econometric expertise with us. We would also like to thank John Campbell and Kenneth French for making data available on-line. This project was started when Lustig was at the University of Chicago. The views expressed herein are those of the author(s) and do not necessarily reflect the views of the National Bureau of Economic Research.

(C) 2005 by Hanno Lustig and Adrien Verdelhan. All rights reserved. Short sections of text, not to exceed two paragraphs, may be quoted without explicit permission provided that full credit, including $\odot$ notice, is given to the source. 
The Cross-Section of Currency Risk Premia and US Consumption Growth Risk Hanno Lustig and Adrien Verdelhan

NBER Working Paper No. 11104

February 2005, Revised September 2006

JEL No. G0, F3

\begin{abstract}
$\underline{\text { ABSTRACT }}$
Aggregate consumption growth risk explains why low interest rate currencies do not appreciate as much as the interest rate differential and why high interest rate currencies do not depreciate as much as the interest rate differential. We sort foreign T-bills into portfolios based on the nominal interest rate differential with the US, and we test the Euler equation of a US investor who invests in these currency portfolios. US investors earn negative excess returns on low interest rate currency portfolios and positive excess returns on high interest rates currency portfolios. We find that low interest rate currencies provide US investors with a hedge against US aggregate consumption growth risk, because these currencies appreciate on average when US consumption growth is low, while high interest rate currencies depreciate when US consumption growth is low. As a result, the risk premia predicted by the Consumption-CAPM match the average excess returns on these currency portfolios.

Hanno Lustig

Department of Economics

UCLA

Box 951477

Los Angeles, CA 90095-1477

and NBER

hlustig@econ.ucla.edu

Adrien Verdelhan

University of Chicago

adrien@uchicago.edu
\end{abstract}


When the foreign interest rate is higher than the US interest rate, risk-neutral and rational US investors should expect the foreign currency to depreciate against the dollar by the difference between the two interest rates. This way, borrowing at home and lending abroad or vice-versa produces a zero return in excess of the US short-term interest rate. This is known as the uncovered interest rate parity (UIP) condition, and it is violated in the data, except in the case of very high inflation currencies. In the data, higher foreign interest rates almost always predict higher excess returns for a US investor in foreign currency markets.

We show that these excess returns compensate the US investor for taking on more US consumption growth risk. High foreign interest rate currencies on average depreciate against the dollar when US consumption growth is low, while low foreign interest rate currencies do not. The textbook logic we use for any other asset can be applied to exchange rates, and it works. If an asset offers low returns when the investor's consumption growth is low, it is risky, and the investor wants to be compensated through a positive excess return.

To uncover the link between exchange rates and consumption growth, we build eight portfolios of foreign currencies excess returns on the basis of the foreign interest rates, because investors know these predict excess returns. Portfolios are re-balanced every period, so the first portfolio always contains the lowest interest rate currencies and the last portfolio always contains the highest interest rate currencies. This is the key innovation in our paper.

Over the last three decades, in empirical asset pricing, the focus has shifted from explaining individual stock returns to explaining the returns on portfolios of stocks, sorted on variables that we know predict returns (e.g. size and book-to-market). ${ }^{1}$ This procedure eliminates the diversifiable, stock-specific component of returns that is not of interest, thus producing much sharper estimates of the risk-return trade-off in equity markets. Similarly, for currencies, by sorting these into portfolios, we abstract from the currency-specific component of exchange rate changes that is not related to changes in the interest rate. This isolates the source of variation in excess returns that interests

\footnotetext{
${ }^{1}$ See Fama (1976), one of the initial advocates of building portfolios, for a clear exposition.
} 
us, and it creates a large average spread of up to five hundred basis points between low and high interest rate portfolios. This spread is an order of magnitude larger than the average spread for any two given countries. As one would expect from the empirical literature on UIP, US investors earn on average negative excess returns on low interest rate currencies of minus 2.3 percent and large, positive excess returns on high interest rate currencies of up to 3 percent. The relation is almost monotonic, as shown in figure 1. These returns are large even when measured per unit of risk. The Sharpe ratio (defined as the ratio of the average excess return to its standard deviation) on the high interest rate portfolio is close to 40 percent, only slightly lower than the Sharpe ratio on US equity, while the same ratio is minus 40 percent for the lowest interest rate portfolio. In addition, these portfolios keep the number of covariances that must be estimated low, while allowing us to continuously expand the number of countries studied as financial markets open up to international investors. This enables us to include data from the largest possible set of countries.

To show that the excess returns on these portfolios are due to currency risk, we start from the US investor's Euler equation and use consumption-based pricing factors. We test the model on annual data for the periods 1953-2002 and 1971-2002.

Consumption-based models explains up to eighty percent of the variation in currency excess returns across these eight currency portfolios. Are the parameter estimates reasonable? Our results are not consistent with what most economists view as plausible values of risk aversion, but they are consistent with the evidence from other assets. The estimated coefficient of risk aversion is around 100, and the estimated price of US consumption growth risk is about 2 percent per annum for nondurables and 4.5 percent for durables. Consumption-based models can explain the risk premia in currency markets only if we are willing to entertain high levels of risk aversion, as is the case in other asset markets. In fact, currency risk seems to be priced much like equity risk. If we estimate the model on US domestic bond portfolios (sorted by maturity) and stock portfolios (sorted by book-to-market and size) in addition to the currency portfolios, the risk aversion estimate does not change. Our currency portfolios really allow for an 'out-of-sample' test of consumption-based models, because the low interest rate cur- 

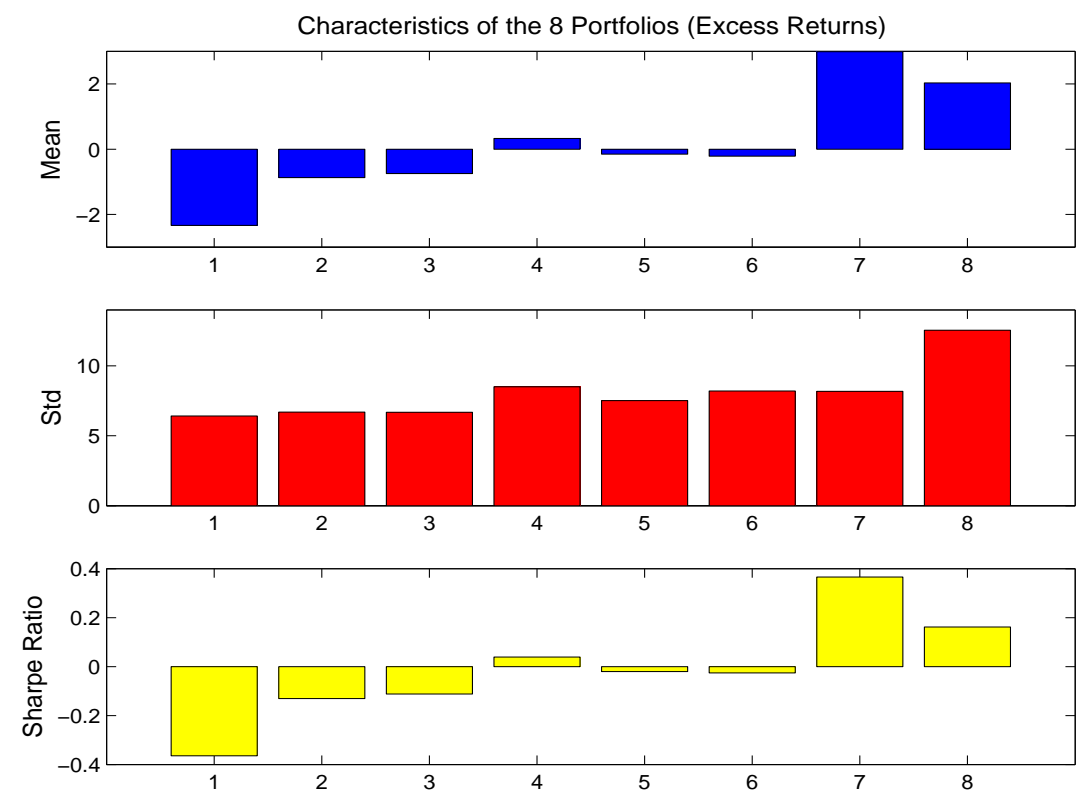

Figure 1: 8 Currency Portfolios.

This figure presents means, standard deviations (in percentages) and Sharpe ratios of real excess returns on 8 annually re-balanced currency portfolios for a US investor. The data are annual and the sample is 1953-2002. These portfolios were constructed by sorting currencies into eight groups at time $t$ based on the nominal interest rate differential with the home country at the end of period $t-1$. Portfolio 1 contains currencies with the lowest interest rates. Portfolio 8 contains currencies with the highest interest rates.

rency portfolios have negative average excess returns, unlike most of the test assets in the empirical asset pricing literature, and the returns on the currency portfolios are not strongly correlated with bond and stock returns.

Consumption-based models can explain the cross-section of currency excess returns if and only if high interest rate currencies typically depreciate when real US consumption growth is low, while low interest rate currencies appreciate. This is exactly the pattern we find in the data. We can restate this result in standard finance language using the consumption growth beta of a currency. The consumption growth beta of a currency measures the sensitivity of the exchange rate to changes in US consumption growth. These betas are small for low interest rate currencies and large for high interest rate currencies. In addition, for the low interest rate portfolios, the betas turn negative when the interest rate gap with the US is large. All our results build on this finding. 
Section I outlines our empirical framework and defines the foreign currency excess returns and the potential pricing factors. Section II tests consumption-based models on the unconditional moments of our foreign currency portfolio returns. Section III links our results to properties of exchange rate betas. Section IV checks the robustness of our estimates in various ways. Finally, section $\mathrm{V}$ concludes with a review of the relevant literature. Data on currency returns and the composition of the currency portfolios are available on the authors' web sites. ${ }^{2}$

\section{Foreign Currency Excess Returns}

This section first defines the excess returns on foreign T-bill investments and details the construction and characteristics of the currency portfolios. We then turn to the US investor's Euler equation and we explain how consumption risk can explain the average excess returns on these currency portfolios.

\section{A Why Build Portfolios of Currencies?}

We focus on a US investor who invests in foreign T-bills or equivalent instruments. These bills are claims to a unit of foreign currency one period from today in all states of the world. $R_{t+1}^{i}$ denotes the risky dollar return from buying a foreign T-bill in country $i$, selling it after one period and converting the proceeds back into dollars: $R_{t+1}^{i}=R_{t}^{i, £} \frac{E_{t+1}^{i}}{E_{t}^{i}}$, where $E_{t}^{i}$ is the exchange rate in dollar per unit of foreign currency, $R_{t}^{i, £}$ is the risk-free one-period return in units of foreign currency $i{ }^{3}$ We use $P_{t}$ to denote the dollar price of the US consumption basket. Finally, $R_{t+1}^{i, e}=\left(R_{t+1}^{i}-R_{t}^{\$}\right) \frac{P_{t}}{P_{t+1}}$ is the real excess return from investing in foreign T-bills, and $R_{t}^{\$}$ is the nominal risk-free rate in US currency. Below, we use lowercase symbols to denote the log of a variable.

\footnotetext{
${ }^{2}$ See http://www.econ.ucla.edu/people/faculty/Lustig.html or http://people.bu.edu/av/.

${ }^{3}$ Note that returns are dated by the time they are known. Thus, $R_{t}^{i, £}$ is the nominal risk free rate between period $t$ and $t+1$, which is known at date $t$.
} 
UIP regressions and Currency Risk premia According to the UIP condition, the slope in a regression of the change in the exchange rate for currency $i$ on the interest rate differential is equal to one:

$$
-\Delta e_{t+1}^{i}=\alpha_{0}^{i}+\alpha_{1}^{i}\left(R_{t}^{i, £}-R_{t}^{\$}\right)+\epsilon_{t+1}^{i}
$$

and the constant is equal to zero. The data consistently produce slope coefficients less than one, mostly even negative. ${ }^{4}$ Of course, this immediately implies that the (nominal) expected excess returns, which are roughly equal to $\left(R_{t}^{i, £}-R_{t}^{\$}\right)+E_{t} \Delta e_{t+1}^{i}$, are not zero and that they are predicted by interest rates: higher interest rates predict higher excess returns.

Currency Portfolios To better analyze the risk-return trade-off for a US investor investing in foreign currency markets, we construct currency portfolios that zoom in on the predictability of excess returns by foreign interest rates.

At the end of each period $t$, we allocate countries to eight portfolios on the basis of the nominal interest rate differential, $R_{t}^{i, £}-R_{t}^{\$}$, observed at the end of period $t$. The portfolios are rebalanced every year. They are ranked from low to high interests rates, portfolio 1 being the portfolio with the lowest interest rate currencies and portfolio 8 being the one with the highest interest rate currencies. By building portfolios, we filter out currency changes that are orthogonal to changes in interest rates. Let $N_{j}$ denote the number of currencies in portfolio $j$, and let us simply assume that currencies within a portfolio have the same UIP constant and slope coefficients. Then, for portfolio $j$, the change in the 'average' exchange rate will reflect mainly the risk premium component, $\alpha_{0}^{j}+\alpha_{1}^{j} \frac{1}{N_{j}} \sum_{i}\left(R_{t}^{i, £}-R_{t}^{\$}\right)$, the part we are interested in.

We always use a total number of eight portfolios. Given the limited number of countries, especially at the start of the sample, we did not want too many portfolios. If we choose less than eight portfolios, then the currencies of countries with very high inflation end up being mixed with others. It is important to keep these currencies

\footnotetext{
${ }^{4}$ See Hansen and Hodrick (1980) and Fama (1984). Hodrick (1987) and Lewis (1995) provide extensive surveys and updated regression results.
} 
separate because the returns on these very high interest rate currencies are very different, as will become more apparent below.

Next, we compute excess returns of foreign T-bill investments $R_{t+1}^{j, e}$ for each portfolio $j$ by averaging across the different countries in each portfolio. We use $E_{T}$ to denote the sample mean for a sample of size $T$. The variation in average excess returns $E_{T}\left[R_{t+1}^{j, e}\right]$ for $j=1, \ldots, 8$ across portfolios is much larger than the spread in average excess returns across individual currencies, because foreign interest rates fluctuate over time: the foreign excess return is positive (negative) when foreign interest rates are high (low), and periods of high excess returns are canceled out by periods of low excess returns. Our portfolios shift the focus from individual currencies to high vs. low interest rate currencies, in the same way that the Fama and French (1992) portfolios of stocks sorted on size and book-to-market ratios shift the focus from individual stocks to small/value vs. large/growth stocks.

\section{B Data}

With these eight portfolios, we consider two different time-horizons. First, we study the period 1953 to 2002, which spans a number of different exchange rate arrangements. The Euler equation restrictions are valid regardless of the exchange rate regime. Second, we consider a shorter time period, 1971 to 2002, beginning with the demise of BrettonWoods.

Interest Rates and Exchange Rates For each currency, the exchange rate is the end-of-month average daily exchange rate, from Global Financial Data. The foreign interest rate is the interest rate on a 3 -month government security (e.g. a US T-bill) or an equivalent instrument, also from Global Financial Data. We used the 3-month interest rate instead of the one-year rate, simply because fewer governments issue bills or equivalent instruments at the one year maturity. As data became available, new countries were added to these portfolios. As a result, the composition of the portfolio as well as the number of countries in a portfolio changes from one period to the next. 
Section A.1 in the Appendix contains a detailed list of the currencies in our sample.

Two additional issues need to be dealt with: the existence of expected and actual default events, and the effects of financial liberalization.

Default Defaults can impact our currency returns in two ways. First, expected defaults should lead rational investors to ask for a default premium, thus increasing the foreign interest rate and the foreign currency return. To check that our results are due to currency risk, we run all experiments for a sub-sample of developed countries. None of these countries has ever defaulted, nor were they ever considered likely candidates. Yet, we obtain very similar results. Second, actual defaults modify the realized returns. To compute actual returns on an investment after default, we used the data set of defaults compiled by Reinhart, Rogoff and Savastano (2003). The (ex ante) recovery rate we applied is seventy percent. This number reflects two sources, Singh (2003) and Moody's Investors Service (2003), presented in section A.2 of the Appendix. If a country is still in default in the following year, we simply exclude it from the sample for that year. ${ }^{5}$

Capital Account Liberalization The restrictions imposed by the Euler equation on the joint distribution of exchange rates and interest rates only make sense if foreign investors can in fact purchase local T-bills. Quinn (1997) has built indices of openness based on the coding of the IMF Annual Report on Exchange Arrangements and Exchange Restrictions. This report covers fifty-six nations from 1950 onwards and 8 more starting in 1954-1960. Quinn (1997)'s capital account liberalization index ranges from zero to one hundred. We chose a cut-off value of 20 , and we eliminate countries below the cutoff. In these countries, approval of both capital payments and receipts are rare, or the payments and receipts are at best only infrequently granted.

\footnotetext{
${ }^{5}$ In the entire sample from 1953 to 2002 , there are thirteen instances of default by a country whose currency is in one of our portfolios: Zimbabwe (1965), Jamaica (1978), Jamaica (1981), Mexico (1982), Brazil (1983), Philippines (1983), Zambia (1983), Ghana (1987), Jamaica (1987), Trinidad and Tobago (1988), South Africa $(1989,1993)$ and Pakistan (1998). Of course, many more countries actually defaulted over this sample, but those are not in our portfolios because they imposed capital controls, as explained in the next paragraph.
} 


\section{Summary Statistics for the Currency Portfolio Returns}

This section present some preliminary evidence on the currency portfolio returns.

Table 1: US Investor's Excess Returns

\begin{tabular}{lcccccccc}
\hline \hline Portfolio & 1 & 2 & 3 & 4 & 5 & 6 & 7 & 8 \\
\hline \multirow{2}{*}{ mean } & -2.34 & -0.87 & -0.75 & 0.33 & -0.15 & -0.21 & 2.99 & 2.03 \\
SR & -0.36 & -0.13 & -0.11 & 0.04 & -0.02 & -0.03 & 0.37 & 0.16 \\
\hline \multirow{2}{*}{ mean } & -2.99 & -0.01 & -0.83 & 1.14 & -0.69 & -0.00 & 3.94 & 1.48 \\
SR & -0.38 & -0.00 & -0.10 & 0.11 & -0.07 & -0.00 & 0.39 & 0.10 \\
\hline \hline
\end{tabular}

Notes: This table reports the mean of the real excess returns (in percentage points) and the Sharpe Ratio (SR) for a US investor. The portfolios are constructed by sorting currencies into eight groups at time $t$ based on the nominal interest rate differential at the end of period $t-1$. Portfolio 1 contains currencies with the lowest interest rates. Portfolio 8 contains currencies with the highest interest rates. The table reports annual returns for annually re-balanced portfolios.

The first panel of table 1 lists the average excess return in units of US consumption $E_{T}\left[R_{t+1}^{j, e}\right]$ and the Sharpe ratio for each of the annually re-balanced portfolios. The largest spread (between the first and the seventh portfolio) exceeds five percentage points for the entire sample, and close to seven percentage points in the shorter sub-sample. The average annual returns are almost monotonically increasing in the interest rate differential. The only exception is the last portfolio, which consists of very high inflation currencies: the average interest rate gap with the US for the eighth portfolio is about 16 percentage points over the entire sample and 23 percentage points post-Bretton Woods. As Bansal and Dahlquist (2000) have documented, UIP tends to work best at high inflation levels.

Countries change portfolios frequently (23 percent of the time), and the time-varying composition of the portfolios is critical. If we allocate currencies into portfolios based on the average interest rate differential over the entire sample instead, then there is essentially no pattern in average excess returns.

Exchange Rates and Interest Rates Table 2 decomposes the average excess returns on each portfolio into its two components. For each portfolio, we report the average 
Table 2: Exchange Rates and Interest Rates

\begin{tabular}{lccccccccc}
\hline \hline Portfolio & 1 & 2 & 3 & 4 & 5 & 6 & 7 & 8 \\
\hline & \multicolumn{7}{c}{ 1953-2002 } \\
\cline { 2 - 9 }$E_{T}\left(\Delta R^{j}\right)$ & -2.46 & -1.20 & -0.77 & 0.14 & 1.12 & 2.52 & 4.69 & 16.36 \\
$E_{T}\left(-\Delta e^{j}\right)$ & 0.34 & 0.26 & 0.41 & 0.29 & 1.69 & 3.08 & 2.18 & 15.72 \\
$E_{T}\left(\Delta p^{j}\right)$ & 4.12 & 4.66 & 4.19 & 5.14 & 5.63 & 6.19 & 7.67 & 15.20 \\
\hline & & & \multicolumn{7}{c}{$1971-2002$} \\
$E_{T}\left(\Delta R^{j}\right)$ & -2.94 & -1.43 & -0.44 & 0.74 & 2.31 & 4.00 & 6.84 & 22.96 \\
$E_{T}\left(-\Delta e^{j}\right)$ & 0.74 & -0.83 & 0.47 & 0.33 & 2.96 & 4.17 & 3.65 & 23.74 \\
$E_{T}\left(\Delta p^{j}\right)$ & 4.72 & 5.53 & 4.93 & 6.05 & 6.95 & 7.72 & 10.23 & 20.92 \\
\hline \hline
\end{tabular}

Notes: This table reports the time-series average of the average interest rate differential $\Delta R_{t}^{j}$ (in percentage points), the average rate of depreciation (in percentage points) $\Delta e_{t+1}^{j}$ and the average inflation rate $\Delta p^{j}$ (in percentage points) for each of the portfolios. Portfolio 1 contains currencies with the lowest interest rates. Portfolio 8 contains currencies with the highest interest rates. This table reports annual interest rates, exchange rate changes and inflation rates for annually re-balanced portfolios.

interest rate gap $\left(E_{T}\left(\Delta R^{j}\right)\right)$ in the first row of each panel in Table 2 and the average rate of depreciation $\left(E_{T}\left(-\Delta e^{j}\right)\right)$ in the second row. ${ }^{6}$ If there is no average risk premium, these should be identical. Table 2 shows they are not. Investors earn large negative excess returns on the first portfolio because the low interest rate currencies in the first portfolio depreciate on average by 34 basis points, while the average foreign interest rate is 2.46 percentage points lower then the US interest rate. On the other hand, the higher interest rate currencies in the seventh portfolio depreciate on average by almost 2.18 percentage points, but the average interest rate difference is on average 4.7 percentage points. The third row in each panel reports the inflation rates. As advertised, for the very high interest rate currencies in the last portfolio, much of the interest rate gap reflects inflation differences. This is not the case for low interest rate portfolios.

Our currency portfolios create a stable set of excess returns. In order to explain the variation in these currency excess returns, we use consumption-based pricing kernels.

\footnotetext{
${ }^{6} \Delta R_{t}^{j}$ is the average interest rate differential $\frac{1}{N_{j}} \sum_{i}\left(R_{t}^{i, £}-R_{t}^{\$}\right)$ for portfolio $j$ at time $t$. The average risk premium is approximately equal to the difference between the first and the second row. This approximation does not exactly lead to the excess return reported in Table 1, because Table 1 reports the real excess return (based on the real return on currency and the real US risk-free rate), and because of the log approximation.
} 


\section{US Investor's Euler Equation}

We turn now to a description of the US investor preferences. We use $M_{t+1}$ to denote the US investor's real stochastic discount factor (SDF) or intertemporal marginal rate of substitution, in the sense of Hansen and Jagannathan (1991). This discount factor prices payoffs in units of US consumption. In the absence of short-sale constraints or other frictions, the US investor's Euler equation for foreign currency investments holds for each currency $i$ and thus for each portfolio $j$ :

$$
E_{t}\left[M_{t+1} R_{t+1}^{j, e}\right]=0
$$

Preferences Our consumption-based asset pricing model is derived in a standard representative agent setting, following Lucas (1978) and Breeden (1979), and its extension to non-expected utility by Epstein and Zin (1989) and to durable goods by Dunn and Singleton (1986) and Eichenbaum and Hansen (1990). We adopt Yogo (2006)'s setup which conveniently nests all these models. The stand-in household has preferences over non-durable consumption $C_{t}$ and durable consumption services $D_{t}$. Following Yogo (2006), the stand-in household ranks stochastic streams of non-durable and durable consumption $\left\{C_{t}, D_{t}\right\}$ according to the following utility index:

$$
U_{t}=\left\{(1-\delta) u\left(C_{t}, D_{t}\right)^{1-\frac{1}{\sigma}}+\delta E_{t}\left[U_{t+1}^{1-\gamma}\right]^{\frac{1}{\kappa}}\right\}^{1 /\left(1-\frac{1}{\sigma}\right)}
$$

where $\kappa=(1-\gamma) /(1-1 / \sigma) . \delta$ is the subjective time discount factor, $\gamma>0$ governs the household's risk aversion and $\sigma>0$ is the elasticity of intertemporal substitution (EIS). The one-period utility kernel is given by a CES-function over $C$ and $D$ :

$$
u(C, D)=\left[(1-\alpha) C^{1-\frac{1}{\rho}}+\alpha D^{1-\frac{1}{\rho}}\right]^{1 /\left(1-\frac{1}{\rho}\right)},
$$

$\alpha \in(0,1)$ is the weight on durable consumption and $\rho \geq 0$ is the intratemporal elasticity of substitution between non-durables and durables. Yogo (2006)'s model, which we refer to as the $E Z-D C A P M$, nests four familiar models. Table 3 lists all of these. On the 
one hand, if we impose $\gamma=1 / \sigma$, the Durable Consumption-CAPM (DCAPM) obtains, while imposing $\rho=\sigma$ produces the Epstein-Zin Consumption-CAPM (EZ-CCAPM). When $\gamma=1 / \sigma$ and $\rho=\sigma$, the standard Breeden-Lucas CCAPM obtains.

Table 3: Nested Models

\begin{tabular}{ccccc}
\hline \hline Parameters & CCAPM & DCAPM & EZ-CCAPM & CAPM \\
\hline$\gamma$ & $1 / \sigma$ & $1 / \sigma$ & $\rho$ & $\sigma=\rho \rightarrow \infty$ \\
$\sigma$ & $\rho$ & & $\kappa / \sigma$ & 0 \\
\hline & \multicolumn{5}{c}{ Linear Factor Model Loadings } \\
$b_{c}$ & $\gamma$ & $\gamma+\alpha(1 / \rho-\gamma)$ & $\kappa$ & 0 \\
$b_{d}$ & 0 & $\kappa \alpha(1 / \sigma-1 / \rho)$ & 0 & $\gamma$ \\
$b_{m}$ & 0 & 0 & $1-\kappa$ & $\gamma$ \\
\hline \hline
\end{tabular}

Notes: $\gamma$ is the coefficient of risk aversion, $\rho$ is the intratemporal elasticity of substitution between non-durables $C$ and durables $D$ consumption, $\sigma$ is the elasticity of intertemporal substitution, $\kappa=(1-\gamma) /(1-1 / \sigma)$.

As shown by Yogo (2006), the intertemporal marginal rate of substitution (IMRS) of the stand-in agent is given by:

$$
M_{t+1}=\left[\delta\left(\frac{C_{t+1}}{C_{t}}\right)^{-\frac{1}{\sigma}} \frac{v\left(D_{t+1} / C_{t+1}\right)^{1 / \rho-1 / \sigma}}{v\left(D_{t} / C_{t}\right)}\left(R_{t+1}^{w}\right)^{1-1 / \kappa}\right]^{\kappa}
$$

where $R^{w}$ is the return on the market portfolio and $v$ is defined as:

$$
v(D / C)=\left[1-\alpha+\alpha\left(\frac{D}{C}\right)^{1-1 / \rho}\right]^{1 /\left(1-\frac{1}{\rho}\right)} .
$$

\section{E Calibration}

We start off by feeding actual consumption and return data into a calibrated version of our model, and we assess how much of the variation in currency excess returns this calibrated model can account for. To do so, we take Yogo (2006)'s estimates of the substitution elasticities and the durable consumption weight in the utility function. ${ }^{7}$ Next, we feed the data for $C_{t}, D_{t}$ and $R_{t}^{w}$, the market return into the SDF in 2 , and we

\footnotetext{
${ }^{7}$ We fix $\sigma$ at $.023, \alpha$ at .802 and $\rho$ at .700. These parameters were estimated from a US investor's Euler equation on a large number of equity portfolios (Yogo (2006), p. 552, Table II, All Portfolios).
} 
simply evaluate the pricing errors $E_{T}\left[M_{t+1} R_{t+1}^{j, e}\right]$ for each portfolio $j . \gamma$ was chosen to minimize the mean squared pricing error on the 8 currency portfolios. ${ }^{8}$ Table 4 reports the implied maximum Sharpe ratio (first row), the market price of risk (row 2), the standard error (row 3), the mean absolute pricing error ( $M A E$, in row 4), as well as the $R^{2}$. The benchmark model in the last column explains $65 \%$ of the cross-sectional variation with $\gamma$ equal to 30 . To understand this result, it helps to decompose the model's predicted excess return on currency portfolio $j$ in the price of risk and the risk beta:

$$
E_{T}\left(R_{t+1}^{j, e}\right)=\underbrace{\frac{-\operatorname{cov}_{T}\left[M_{t+1}, R_{t+1}^{j, e}\right]}{\operatorname{var}_{T}\left[M_{t+1}\right]}}_{\beta_{M}^{j}} \underbrace{\frac{\operatorname{var}_{T}\left[M_{t+1}\right]}{E_{T}\left[M_{t+1}\right]}}_{\text {price of risk }} .
$$

There is a large difference in risk exposure between the first and the seventh portfolios: $\beta_{M}^{1}$ is -2.54 , while $\beta_{M}^{7}$ is 8.21 . When multiplied by the price of risk of 28 basis points, this translates into a 3 percentage point spread in the predicted excess return between the first and the seventh portfolio, about $65 \%$ of the actual spread. The low interest rate portfolio provides the US investor with protection against high marginal utility growth, or high $M$, states of the world, while the high interest rate portfolios do not. This variation in betas is the focus of the next section.

Table 4: Calibrated Non-Linear Model tested on 8 Currency Portfolios sorted on Interest Rates

\begin{tabular}{lcccc}
\hline \hline & CCAPM & DCAPM & EZ-CCAPM & EZ-DCAPM \\
\hline $\operatorname{std}_{T}[M] / E_{T}[M]$ & 0.698 & 0.902 & 0.433 & 0.705 \\
$\operatorname{var}_{T}[M] / E_{T}[M]$ & 0.346 & 0.452 & 0.141 & 0.286 \\
$M A E$ & 0.929 & 0.868 & 0.947 & 0.840 \\
$R^{2}$ & 0.556 & 0.639 & 0.498 & 0.673 \\
\hline \hline
\end{tabular}

Notes: This table reports the risk prices and the measures of fit for a calibrated model on 8 annually re-balanced currency portfolios. The sample is 1953-2002 (annual data). The first two rows report the maximum Sharpe ratio (row 1) and the price of risk (row 2). The last two rows report the mean absolute pricing error (in percentage points) and the $R^{2}$. Following Yogo (2006), we fixed $\sigma$ at .023 (EZ-CCAPM and EZ-DCAPM), $\alpha$ at .802 (DCAPM and EZ-DCAPM) and $\rho$ at $.700(D C A P M, E Z-D C A P M) . \gamma$ is fixed at 30.34 to minimize the mean squared pricing error in the $E Z-D C A P M$. $\delta$ is set to .98 .

\footnotetext{
${ }^{8}$ As a result of these high levels of risk aversion in a growing economy, our model cannot match the risk-free rate.
} 


\section{Does Consumption Risk Explain Foreign Currency Excess Returns?}

So far, we have engineered a large cross-sectional spread in currency excess returns by sorting currencies into portfolios, and we have shown that a calibrated version of the model explains a large fraction of this spread. In this section, starting from the Euler equation and following Yogo (2006), we derive a linear factor model whose factors are non-durable US consumption growth $\Delta c_{t}$, durable US consumption growth $\Delta d_{t}$ and the $\log$ of the US market return $r_{t}^{m}$. Using standard linear regression methods, we show that US consumption risk explains most of the variation in average excess returns across the eight currency portfolios, because on average low interest rate currencies expose US investors to less non-durable and durable consumption risk than high interest rate currencies. We start by deriving the factor model, then we describe the estimation method and we present our results in terms of fit, factor prices and preference parameters.

\section{A Linear Factor Model}

The US investor's unconditional Euler equation (approximately) implies a linear threefactor model for the expected excess return on portfolio $j:^{9}$

$$
E\left[R^{j, e}\right]=b_{1} \operatorname{cov}\left(\Delta c_{t}, R_{t}^{j, e}\right)+b_{2} \operatorname{cov}\left(\Delta d_{t}, R_{t}^{j, e}\right)+b_{3} \operatorname{cov}\left(r_{t}^{w}, R_{t+1}^{j, e}\right)
$$

The vector of factor loadings $b$ depend on the preference parameters $\sigma, \alpha$ and $\rho$ :

$$
b=\left[\begin{array}{c}
\kappa[1 / \sigma+\alpha(1 / \rho-1 / \sigma)] \\
\kappa \alpha(1 / \sigma-1 / \rho) \\
1-\kappa
\end{array}\right] .
$$

\footnotetext{
${ }^{9}$ This linear factor model is derived by using a linear approximation of the SDF $M_{t+1}$ around its unconditional mean:

$$
\frac{M_{t+1}}{E\left[M_{t+1}\right]} \simeq 1+m_{t+1}-E\left[m_{t+1}\right]
$$

where lower letters denote logs. Since we use excess returns, we normalize the constant in the SDF to 1 , because we cannot identify it from the estimation.
} 
The expected excess return on portfolio $j$ is governed by the covariance of its returns with non-durable consumption growth, durable consumption growth and the market return. When $b_{1}>0$ (the case that obtains when $\gamma>1$ and $\sigma<1$ ), then an asset with high non-durable consumption growth beta must have a high expected excess return. This turns out to be the empirically relevant case. $b_{2}>0$ obtains when the intratemporal elasticity of substitution is larger than the EIS. In this case, an asset with a high durable consumption growth beta also has a high expected excess return. In this range of the parameter space, nondurables and durables are good substitutes, and as a result, high durable consumption can offset the effect of low nondurable consumption on marginal utility.

Our benchmark asset pricing model, denoted $E Z-D C A P M$, is described by equation (3). This specification however nests the CCAPM with $\Delta c_{t}$ as the only factor, the $D C A P M$ with $\Delta c_{t}$ and $\Delta d_{t}$ as factors, the EZ-CCAPM, with $\Delta c_{t}$ and $r_{t}^{w}$, and, finally the $C A P M$ as special cases, as shown in the bottom panel of Table 3.

Beta Representation This linear factor model can be restated as a beta pricing model, where the expected excess return is equal to the factor price $\lambda$ times the amount of risk of each portfolio $\beta^{j}$ :

$$
E\left[R^{j, e}\right]=\lambda^{\prime} \beta^{j}
$$

where $\lambda=\Sigma_{f f} b$ and $\Sigma_{f f}=E\left(f_{t}-\mu_{f}\right)\left(f_{t}-\mu_{f}\right)^{\prime}$ is the variance-covariance matrix of the factors.

A Simple Example A simple example will help to understand what is needed for consumption growth risk to explain the cross-section of currency returns. Let us start with the plain-vanilla $C C A P M$. The only asset pricing factor is aggregate, non-durable consumption growth, $\Delta c_{t+1}$, and the factor loading $b_{1}$ equals the coefficient of risk aversion $\gamma$. We can restate the expected excess return on portfolio $j$ as the product of the 
portfolio beta $\beta_{c}^{j}=\frac{\operatorname{cov}\left(\Delta c_{t}, R_{t}^{j, e}\right)}{\operatorname{var}\left(\Delta c_{t}\right)}$ and the factor price $\lambda_{c}=b_{1} \operatorname{var}\left(\Delta c_{t}\right)$ :

$$
E\left[R_{t}^{j, e}\right]=\frac{\operatorname{cov}\left(\Delta c_{t}, R_{t}^{j, e}\right)}{\operatorname{var}\left(\Delta c_{t}\right)} b_{1} \operatorname{var}\left(\Delta c_{t}\right)=\beta_{c}^{j} \lambda_{c}, \quad j=1 \ldots 8
$$

The factor price measures the expected excess return on an asset that has a consumption growth beta of one. Of course, the CCAPM can explain the variation in returns only if the consumption betas are small/negative for low interest rate portfolios and large/positive for high interest rate portfolios. Essentially, in testing the CCAPM, we gauge how much of the variation in average returns across currency portfolios can be explained by variation in the consumption betas. If the predicted excess returns - the right hand side variable in equation (5) - line up with the realized sample means, then we can claim success in explaining exchange rate changes, conditional on whether the currency is a low or high interest rate currency. A key question then is whether there is enough variation in the consumption betas of these currency portfolios to explain the variation in excess returns with a plausible price of consumption risk. The next section provides a positive answer to this question.

\section{B An Asset Pricing Experiment}

To estimate the factor prices $\lambda$ and the portfolio betas, we use a 2-stage procedure following Fama and MacBeth (1973). ${ }^{10}$ In the first stage, for each portfolio $j$, we run a time-series regression of the currency returns $R_{t+1}^{j, e}$ on a constant and the factors $f_{t}$, in order to estimate $\beta^{j}$. In the second stage, we run a cross-sectional regression of the average excess returns $E_{T}\left[R_{t}^{e}\right]$ on the betas that were estimated in the first stage, to estimate the factor prices $\lambda$. Finally, we can back out the factor loadings $b$ and hence the structural parameters from the factor prices.

We start by testing the consumption-based US investor's Euler equation on the eight annually re-balanced currency portfolios. Table 5 reports the estimated factor prices of

\footnotetext{
${ }^{10}$ Chapter 12 of Cochrane (2001) describes this estimation procedure and compares it to the Generalized Method of Moments (GMM) applied to linear factor models, following Hansen (1982). We present results obtained with GMM as a robustness check in section IV.
} 
consumption growth risk for nondurables (row 1), for durables (row 2) and the price of market risk (row 3). Each column looks at a diferent model. We also report the implied estimates for the preference parameters $\gamma, \sigma$ and $\alpha$ (rows 4-6). The standard errors are in parentheses. ${ }^{11}$ Finally, the last three rows report the mean absolute pricing error $(M A E)$, the $R^{2}$ and the p-value for a $\chi^{2}$ test. The null for the $\chi^{2}$ test is that the true pricing errors are zero and the p-value reports the probability that these pricing errors would have been observed if the consumption-based model was the true model.

\section{Results}

We present results in terms of the factor prices, the fit, the preference parameters and the consumption betas.

Factor Prices In our benchmark model (EZ-DCAPM), reported in the last column of Table 5 , the estimated price of nondurable consumption growth risk $\lambda_{c}$ is positive and statistically significant. An asset with a consumption growth beta of one yields an average risk premium of around 2 percent per annum. This is a large number, but it is quite close to the market price of consumption growth risk estimated on US equity and bond portfolios (see section IV-C.) The estimated price of durable consumption growth risk $\lambda_{d}$ is positive and statistically significant as well. It is around 4.6 percent. These factor price estimates do not vary much across the different models. Finally, market risk is priced at about 3.3 percent per annum, but it is not significantly different from zero.

Model Fit We find that consumption growth risk explains a large share of the crosssectional variation in currency returns. The EZ-DCAPM explains 87 percent of the cross-sectional variation in annual returns on the eight currency portfolios, against 74 percent for the $D C A P M$ and 18 percent for the simple CCAPM. For the EZ-DCAPM, the mean absolute pricing error on these eight currency portfolios is about 32 basis

\footnotetext{
${ }^{11}$ These standard errors do not correct for the fact that the betas are estimated. Jagannathan and Wang (1996) show that the Fama-MacBeth procedure does not necessarily overstate the precision of the standard errors if conditional heteroskedasticity is present. We show in section IV - E that these standard errors are actually close to the heteroskedasticy-consistent ones derived from GMM estimates.
} 
points over the entire sample, compared to 65 basis points for the $D C A P M$, and 200 basis points for the simple $C C A P M$. This last number is rather high, mainly because of the last portfolio, with very high interest rate currencies. When we drop the last portfolio, the mean absolute pricing error on the remaining seven portfolios drops to 109 basis points for the simple $C C A P M$, and the $R^{2}$ increases to 50 percent.

The simple $C C A P M$ and the $E Z-C C A P M$ are rejected at the 5 percent significance levels, but the $D C A P M$ and the EZ-DCAPM are not. Durable consumption risk plays a key role here as the models with durable consumption growth produce very small pricing errors (less than 15 basis points) on the first and the seventh portfolio. This is clear from figure 2, which plots the actual excess return against the predicted excess return (on the horizontal axis) for each of these models.
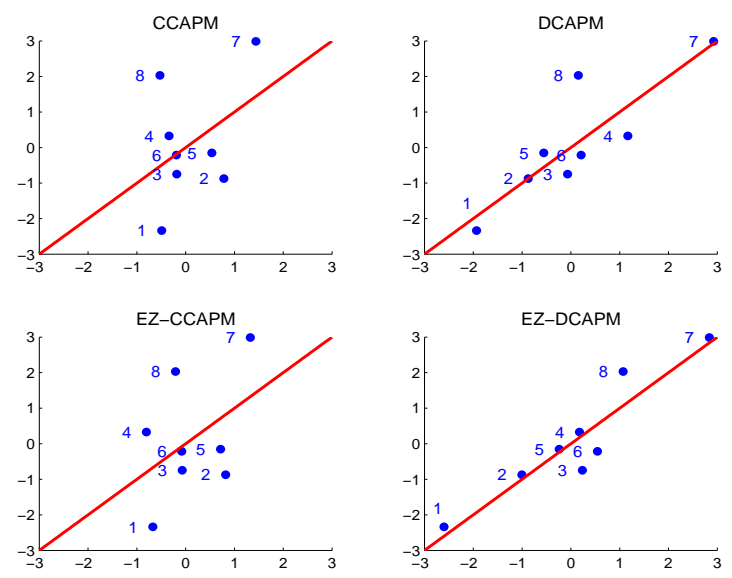

Figure 2: Consumption-CAPM

This figure plots the actual vs. the predicted excess returns for 8 currency portfolios. The predicted excess returns are on the horizontal axis. The Fama-MacBeth estimates are obtained using 8 currency portfolios sorted on interest rates as as test assets. The filled dots (1-8) represent the currency portfolios. The data are annual and the sample is 1953-2002.

Preference Parameters and Equity Premium Puzzle ¿From the factor prices, we can back out the preference parameters. The intratemporal elasticity of substitution between non-durables and durables $\rho$ cannot be separately identified from the weight on durable consumption $\alpha$. We use Yogo (2006)'s estimate of $\rho=.790$ to calibrate the elasticity of intratemporal substitution when we back out the other preference parameter 
Table 5: Estimation of Linear Factor Models with 8 Currency Portfolios sorted on Interest Rates

\begin{tabular}{|c|c|c|c|c|}
\hline & CCAPM & DCAPM & EZ-CCAPM & EZ-DCAPM \\
\hline \multicolumn{5}{|l|}{ Factor Prices } \\
\hline \multirow[t]{2}{*}{ Nondurables } & 1.938 & 1.973 & 2.021 & 2.194 \\
\hline & {$[0.917]$} & [0.915] & {$[0.845]$} & {$[0.830]$} \\
\hline \multirow[t]{2}{*}{ Durables } & & 4.598 & & 4.696 \\
\hline & & {$[0.987]$} & & {$[0.968]$} \\
\hline \multirow[t]{2}{*}{ Market } & & & 8.838 & 3.331 \\
\hline & & & {$[7.916]$} & {$[7.586]$} \\
\hline \multicolumn{5}{|l|}{ Parameters } \\
\hline \multirow[t]{2}{*}{$\gamma$} & 92.032 & 104.876 & 94.650 & 113.375 \\
\hline & [6.158] & {$[6.236]$} & {$[5.440]$} & {$[5.558]$} \\
\hline \multirow[t]{2}{*}{$\sigma$} & & & -0.008 & 0.210 \\
\hline & & & [0.003] & {$[0.056]$} \\
\hline \multirow[t]{2}{*}{$\alpha$} & & 1.104 & & 1.146 \\
\hline & & {$[0.048]$} & & {$[0.001]$} \\
\hline \multicolumn{5}{|l|}{ Stats } \\
\hline$M A E$ & 2.041 & 0.650 & 1.989 & 0.325 \\
\hline$R^{2}$ & 0.178 & 0.738 & 0.199 & 0.869 \\
\hline$p-$ value & {$[0.025]$} & {$[0.735]$} & {$[0.024]$} & {$[0.628]$} \\
\hline
\end{tabular}

Notes: This table reports the Fama-MacBeth estimates of the risk prices (in percentage points) using 8 annually rebalanced currency portfolios as test assets. The sample is 1953-2002 (annual data). The factors are demeaned. The standard errors are reported between brackets. The last three rows report the mean absolute pricing error (in percentage points), the $R^{2}$ and the p-value for a $\chi^{2}$ test.

estimates. The EIS $\sigma$ is estimated to be .2, substantially larger than $1 / \gamma$, and the weight on durable consumption $\alpha$ is estimated to be around 1.1, close to the .9 estimate reported by Yogo (2006), obtained on quarterly equity portfolios. Since the EIS estimate is significantly smaller than the calibrated $\rho$, marginal utility growth decreases in durable consumption growth, and assets whose returns co-vary more with durable consumption growth trade at a discount $\left(b_{2}>0\right)$.

In the benchmark model, the implied coefficient of risk aversion is around 114 and this estimate is quite precise. In addition, these estimates do not very much across the four different specifications of the consumption-based pricing kernel. This coefficient of 
Table 6: Estimation of Factor Betas for 8 Currency Portfolios sorted on Interest Rates

\begin{tabular}{lcccccccc}
\hline \hline \multirow{2}{*}{ Portfolios } & 1 & 2 & 3 & 4 & 5 & 6 & 7 & 8 \\
\hline \multirow{7}{*}{ Non-durables } & 0.105 & 0.762 & 0.263 & 0.182 & 0.634 & 0.260 & 1.100 & 0.085 \\
\cline { 2 - 9 } Durables & 0.240 & 0.489 & 0.636 & 0.892 & 0.550 & 0.695 & $1.298^{*}$ & 0.675 \\
Market & $-0.066^{*}$ & -0.027 & -0.012 & $-0.119^{*}$ & -0.000 & -0.012 & -0.056 & 0.028 \\
\hline \multirow{7}{*}{ Non-durables } & 0.005 & 0.896 & 0.359 & 0.665 & 0.698 & 0.319 & 1.546 & -0.461 \\
Durables & 0.537 & 0.786 & $1.288^{*}$ & $2.032^{*}$ & $1.225^{*}$ & 1.359 & $2.183^{*}$ & 0.845 \\
Market & $-0.106^{*}$ & $-0.099^{*}$ & -0.026 & $-0.171^{*}$ & -0.017 & -0.007 & -0.083 & 0.052 \\
\hline \hline
\end{tabular}

Notes: Each column of this table reports OLS estimates of $\beta^{j}$ in the following time-series regression of excess returns on the factor for each portfolio $j: R_{t+1}^{j, e}=\beta_{0}^{j}+\beta_{1}^{j} f_{t}+\epsilon_{t+1}^{j}$. The estimates are based on annual data. Panel A reports results for 1953-2002 and Panel B reports results for 1971-2002. We use 8 annually re-balanced currency portfolios sorted on interest rates as test assets. * indicates significance at $5 \%$ level. We use Newey-West heteroskedasticity-consistent standard errors with an optimal number of lags to estimate the spectral density matrix following Andrews (1991).

risk aversion is of course very high, but it is in line with stock-based estimates of the coefficient of risk aversion found in the literature, and with our own estimates based on bond and stock returns. For example, if we re-estimate the model only on the 25 FamaFrench equity portfolios, sorted on size and book-to market, the risk aversion estimate is 115 (with a standard error of 4.5). In addition, the linear approximation we adopted causes an underestimate of the market price of consumption risk for a given risk aversion parameter $\gamma$.

These high estimates are not surprising. The standard deviation of US consumption growth (per annum) is only 1.50 percent in our sample. This is Mehra and Prescott (1985)'s equity premium puzzle in disguise; there is not enough aggregate consumption growth risk in the data to explain the level of risk compensation in currency markets at low levels of risk aversion, as is the case in equity markets, but there is enough variation across portfolios in consumption betas to explain the spread, if the risk aversion is large enough to match the levels. We now focus on this cross-section of consumption betas.

Consumption Betas Consumption-based models can account for the cross-section of currency excess returns because they imply a large cross-section of betas. On average, 
higher interest rate portfolios expose US investors to much more US consumption growth risk. Table 6 reports the OLS betas for each of the factors. Panel A reports the results for the entire sample. We find that high interest rate currency returns are strongly procyclical, while low interest rate currency returns are a-cyclical. For nondurables, the first portfolio's consumption beta is 10 basis points, the seventh portfolio's consumption beta is 110 basis points. For durables, the spread is also about 100 basis points, from 24 basis points to 129 basis points. In the second post-Bretton-Woods sub-sample, reported in Panel B, the spread in consumption betas increases to 150 basis points between the first and the seventh portfolio (with betas ranging from zero basis points to 154 basis points for non-durables, and from 50 to 210 basis points for durables). Finally, the market betas of currency returns are much smaller overall.

Next, we estimate the conditional factor betas, conditioning on the interest rate gap with the US, and we find that low interest rate currencies provide a consumption hedge for US investors exactly when US interest rates are high and foreign interest rates are low.

\section{Conditional Factor Betas}

We can go one step further in our understanding of exchange rates by taking into account the time-variation in the conditional consumption growth betas. ${ }^{12}$ It turns out that low interest rate currencies offer a consumption hedge to US investors exactly when the US interest rates are high and foreign interest rates are low. To see this, we consider a simple two-step procedure. We first obtain the U.I.P residuals $\epsilon_{t+1}^{j}$ for each portfolio $j$. We then regress each residual on each factor $f^{k}$, controlling for the interest rates

${ }^{12}$ There is a conditional analogue of the three-factor model in equation (3):

$$
E_{t}\left[R^{i, e}\right]=b_{1} \operatorname{cov}_{t}\left(\Delta c_{t+1}, R_{t+1}^{i, e}\right)+b_{2} \operatorname{cov}_{t}\left(\Delta d_{t+1}, R_{t+1}^{i, e}\right)+b_{3} \operatorname{cov}_{t}\left(r_{t+1}^{w}, R_{t+1}^{i, e}\right)
$$

Since the interest rate is known at $t$, these covariances terms involve only the changes in the exchange rate $\Delta e_{t+1}^{i}$. 
variations in each portfolio:

$$
\epsilon_{t+1}^{j}=\theta_{0}^{j, k}+\theta_{1}^{j, k} f_{t+1}^{k}+\theta_{2}^{j, k} \Delta \widetilde{R}_{t}^{j} f_{t+1}^{k}+\eta_{t+1}^{j, k},
$$

where for expositional purpose we introduce the normalized interest rate difference $\Delta \widetilde{R}_{t}^{i}$, which is zero when the interest rate difference $\Delta R_{t}^{i}$ is at a minimum and hence positive in the entire sample. We use the interest rate differential as the sole conditioning variable, because we know from the work by Meese and Rogoff (1983) that our ability to predict exchange rates is rather limited.

The results are reported in Table 7 . Each bar in figure 3 reports the conditional factor betas for a different portfolio. The first panel reports the nondurable consumption betas, the second panel the durable consumption betas, the third panel reports the market betas. When the interest rate difference with the US hits the lowest point, the currencies in the first portfolio appreciate on average by 287 basis points when US nondurable consumption growth drops 100 basis points below its mean, while the currencies in the seventh portfolio depreciate on average by 96 basis points. Similarly, when US durable consumption growth drops 100 basis points below its mean, the currencies in the first portfolio appreciate by 174 basis points, while the currencies in the seventh portfolio depreciate by 105 basis points. Low interest rate currencies provide consumption insurance to US investors, while high interest rate currencies expose US investors to more consumption risk. As the interest rate gap closes on the currencies in the first portfolio, the low interest rate currencies provide less consumption insurance. For every 4 percentage points reduction in the interest rate gap, the non-durable consumption betas decrease by about 100 basis points. ${ }^{13}$

Interest rates as Instruments To test whether the representative agent's IMRS can indeed explain the time variation in expected returns on these portfolios, in addition to the cross-sectional variation, we use the average interest rate difference with the US as an instrument. As is clear from the unconditional Euler equation, this is equivalent to

\footnotetext{
${ }^{13}$ This table also shows our asset pricing results are entirely driven by how exchange rates respond to consumption growth shocks in the US, not by sovereign risk.
} 

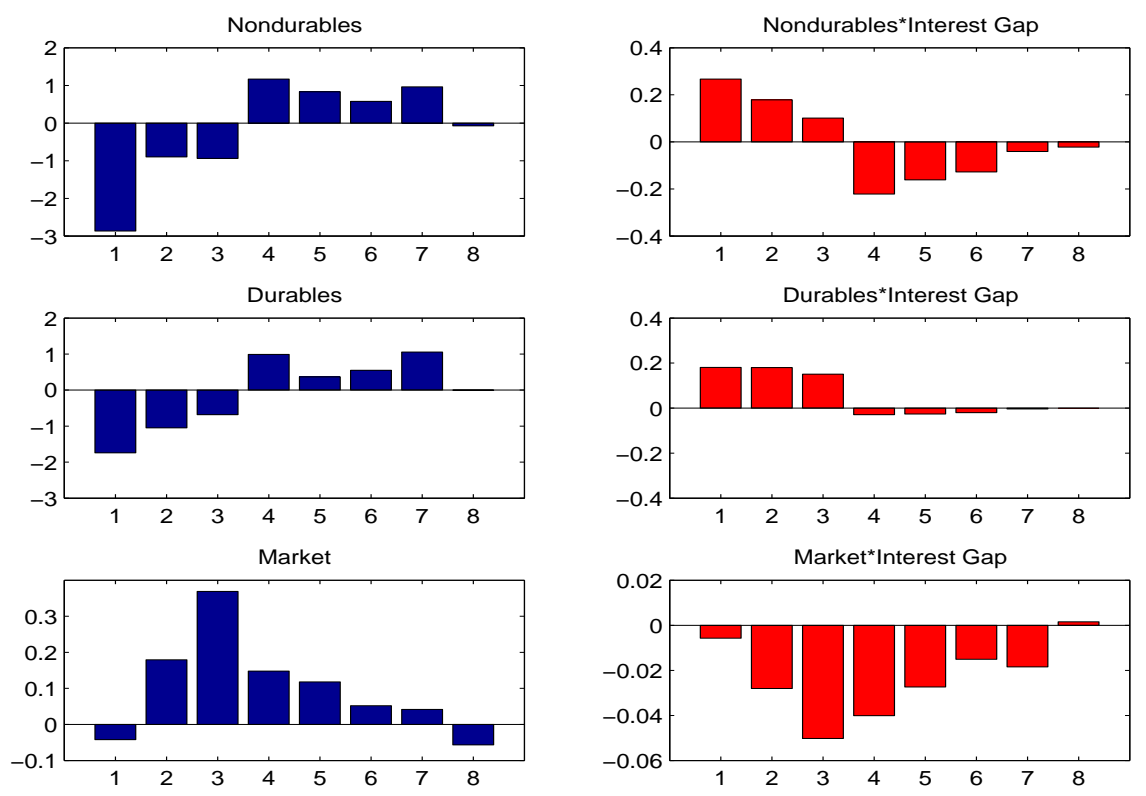

Figure 3: Conditional Factor Betas of Currency

Each panel shows OLS estimates of $\theta_{1}^{j, k}$ (panels on the left) and $\theta_{2}^{j, k}$ (panels on the right) in the following time-series regression of innovations to changes in exchange rate for each portfolio $j$ on the factor and the interest rate difference interacted with the factor: $\epsilon_{t+1}^{j}=\theta_{0}^{j, k}+\theta_{1}^{j, k} f_{t+1}^{k}+\theta_{2}^{j, k} \Delta \widetilde{R}_{t}^{j} f_{t+1}^{k}+\eta_{t+1}^{j, k} . \Delta \widetilde{R}^{j}$ is the normalized interest rate difference on portfolio $j$. The data are annual and the sample is 1953-2002.

testing the unconditional moments of managed portfolio returns:

$$
E\left[M_{t+1}\left(\Delta \widetilde{R}_{t} R_{t+1}^{i, e}\right)\right]=0
$$

where $\Delta R_{t}$ is the average interest rate difference on portfolios 1-7 and $\left(\Delta \widetilde{R}_{t} R_{t+1}^{i, e}\right)$ are the managed portfolio returns. We normalized $\Delta \widetilde{R}_{t}$ to be positive. ${ }^{14}$ Instead of the variation in average portfolio returns, we check whether the model explains the crosssectional variation in average excess returns on managed portfolios that lever up when the interest rate gap with the US is large. In addition, we also use the interest rate difference for each portfolio as an instrument for that asset's Euler equation.

Table 8 reports the Fama-MacBeth estimates of the factor prices and preference parameters for our benchmark model. In the first column, we use the average interest

\footnotetext{
${ }^{14}$ We add $\left|\min \left(\Delta R_{t}\right)\right|$ to the interest rate differential.
} 
Table 7: Estimation of Conditional Consumption Betas for Changes in Exchange Rates on Currency Portfolios Sorted on Interest Rates

\begin{tabular}{|c|c|c|c|c|c|c|c|c|}
\hline & 1 & 2 & 3 & 4 & 5 & 6 & 7 & 8 \\
\hline \multicolumn{9}{|c|}{ Panel A: Non-durables } \\
\hline \multirow[t]{2}{*}{$\theta_{1}^{j, c}$} & -2.87 & -0.90 & -0.94 & 1.17 & 0.83 & 0.58 & 0.96 & -0.08 \\
\hline & {$[0.73]$} & {$[1.20]$} & {$[1.28]$} & {$[1.99]$} & {$[0.91]$} & {$[1.00]$} & {$[0.75]$} & {$[0.90]$} \\
\hline \multirow[t]{2}{*}{$\theta_{2}^{j, c}$} & 0.27 & 0.18 & 0.10 & -0.22 & -0.16 & -0.13 & -0.04 & -0.02 \\
\hline & {$[0.10]$} & {$[0.19]$} & {$[0.17]$} & {$[0.30]$} & {$[0.17]$} & {$[0.14]$} & {$[0.07]$} & [0.03] \\
\hline \multicolumn{9}{|c|}{ Panel B: Durables } \\
\hline \multirow{2}{*}{$\theta_{1}^{j, d}$} & -1.74 & -1.05 & -0.68 & 0.99 & 0.36 & 0.55 & 1.05 & -0.00 \\
\hline & {$[1.01]$} & {$[1.47]$} & [1.39] & {$[1.44]$} & {$[0.92]$} & {$[0.67]$} & {$[0.51]$} & {$[0.53]$} \\
\hline \multirow[t]{2}{*}{$\theta_{2}^{j, d}$} & 0.18 & 0.18 & 0.15 & -0.03 & -0.03 & -0.02 & -0.00 & -0.00 \\
\hline & {$[0.10]$} & {$[0.17]$} & {$[0.17]$} & {$[0.19]$} & {$[0.14]$} & {$[0.08]$} & {$[0.06]$} & {$[0.01]$} \\
\hline \multicolumn{9}{|c|}{ Panel C: Market } \\
\hline \multirow[t]{2}{*}{$\theta_{1}^{j, m}$} & -0.04 & 0.18 & 0.37 & 0.15 & 0.12 & 0.05 & 0.04 & -0.06 \\
\hline & {$[0.13]$} & {$[0.19]$} & {$[0.14]$} & {$[0.24]$} & {$[0.10]$} & {$[0.09]$} & {$[0.06]$} & [0.08] \\
\hline \multirow[t]{2}{*}{$\theta_{2}^{j, m}$} & -0.01 & -0.03 & -0.05 & -0.04 & -0.03 & -0.02 & -0.02 & 0.00 \\
\hline & {$[0.02]$} & {$[0.02]$} & {$[0.02]$} & {$[0.03]$} & {$[0.02]$} & {$[0.01]$} & {$[0.01]$} & {$[0.00]$} \\
\hline
\end{tabular}

Notes: Each column of this table reports OLS estimates of $\theta^{j, k}$ in the following time-series regression of innovations to returns for each portfolio $j\left(\epsilon_{t+1}^{j}\right)$ on the factor $f^{k}$ and the interest rate difference interacted with the factor: $\epsilon_{t+1}^{j}=$ $\theta_{0}^{j, k}+\theta_{1}^{j, k} f_{t+1}^{k}+\theta_{2}^{j, k} \Delta \widetilde{R}_{t}^{j} f_{t+1}^{k}+\eta_{t+1}^{j, k}$. We normalized the interest rate difference $\Delta \widetilde{R}_{t}^{j}$ to be zero when the interest rate difference $\Delta R_{t}^{j}$ is at a minimum and hence positive in the entire sample. $\epsilon_{t+1}^{j}$ are the residuals from the time series regression of changes in the exchange rate on the interest rate difference (UIP regression): $E_{t+1}^{j} / E_{t}^{j}=\phi_{0}^{j}+\phi_{1}^{j} \Delta R_{t}^{j}+\epsilon_{t+1}^{j}$. The estimates are based on annual data and the sample is 1953-2002. We use 8 annually re-balanced currency portfolios sorted on interest rates as test assets. The pricing factors are consumption growth rates in non-durables $(c)$ and durables $(d)$ and the market return $(w)$. The Newey-West heteroskedasticity-consistent standard errors computed with an optimal number of lags to estimate the spectral density matrix following Andrews (1991) are reported in brackets.

rate difference with the US as an instrument. In the second column, we use the interest rate difference for portfolio $i$ as an instrument for the $i$-th moment. The consumption risk price estimates are very close to those we obtained off the unconditional moments of currency returns, and, more importantly, the benchmark model cannot be rejected in either case.

Consumption-based models do a remarkable job in explaining the cross-sectional variation as well as the time variation in returns, albeit at the cost of a very high implied price of aggregate consumption risk. In section IV, we contrast this model's performance with that of the workhorse of modern finance, the Capital Asset Pricing Model. As we show, there is not enough variation in market betas to explain currency returns, but 
Table 8: Estimation of Linear Factor Models with 8 Managed Currency Portfolios sorted on Interest Rates

\begin{tabular}{lcc}
\hline \hline Factor Price & Average $\Delta R$ & Portfolio $\Delta R^{i}$ \\
\hline Nondurables & 1.719 & 1.504 \\
\multirow{2}{*}{ Durables } & {$[0.757]$} & {$[0.830]$} \\
& 4.025 & 4.317 \\
Market & {$[0.974]$} & {$[1.150]$} \\
& 6.868 & 4.134 \\
& {$[9.012]$} & {$[9.008]$} \\
\hline Parameters & & \\
\hline$\gamma$ & 89.407 & 81.148 \\
& {$[5.069]$} & {$[5.616]$} \\
$\sigma$ & 0.131 & 0.073 \\
& {$[0.018]$} & {$[0.009]$} \\
$\alpha$ & 1.403 & 1.783 \\
& {$[0.022]$} & {$[0.030]$} \\
\hline Stats & & \\
\hline$R^{2}$ & 0.873 & 0.995 \\
$p-$ value & 0.202 & 0.346 \\
\hline \hline
\end{tabular}

Notes: This table reports the Fama-MacBeth estimates of the factor prices (in percentage points) for the EZ-DCAPM using 8 annually re-balanced managed currency portfolios as test assets. The sample is 1953-2002 (annual data). In column 1, we use the average interest rate difference with the US on portfolios 1-7 as an instrument. In column 2 , we use the interest rate difference on portfolio $i$ as the instrument for the $i$-th moment. The standard errors are reported between brackets. The factors are demeaned. The last two rows report the $R^{2}$ and the p-value for a $\chi^{2}$ test.

there is enough variation in consumption betas. We conclude that consumption growth risk seems to play a key role in explaining currency risk premia. The next section links our findings about risk premia back to changes in the exchange rates.

\section{Mechanism}

We have shown that predicted currency excess returns line up with realized ones when pricing factors take into account consumption growth risk. This is not mere luck on our part. The next section provides many robustness checks. This section sheds some light on the underlying mechanism: where do these currency betas come from?. We first show 
that the log of the conditional expected return on foreign currency can be restated in terms of the conditional consumption growth betas of exchange rate changes. We then interpret these betas as restrictions on the joint distribution of consumption growth in high and low interest rate currencies.

\section{A Consumption Growth Betas of Exchange Rates}

If we assume that $M_{t+1}$ and $R_{t+1}^{i}$ are jointly, conditionally log-normal, then the Euler equation can be restated in terms of the real currency risk premium (see proof in Appendix B):

$$
\log E_{t} R_{t+1}^{i}-r_{t}^{f}=-\operatorname{Cov}_{t}\left(m_{t+1}, r_{t+1}^{i}-\Delta p_{t+1}\right)
$$

where lower cases denote logs. We refer to this log currency premium as $c r p_{t+1}^{i}$. It is determined by the covariance between the $\log$ of the SDF $m$ and the real return on investment in the foreign T-bill. Substituting the definition of this return into this equation produces the following expression for the log currency risk premium:

$$
\operatorname{crp}_{t+1}^{i}=-\operatorname{Cov}_{t}\left(m_{t+1}, \Delta e_{t+1}^{i}-\Delta p_{t+1}\right)
$$

Note that the interest rates play no role for conditional risk premia; only changes in the deflated exchange rate matter. Using this expression, we examine what restrictions are implied on the joint distribution of consumption growth and exchange rates by the increasing pattern of currency risk premia in interest rates, and we test these restrictions in the data.

Consumption Growth and Exchange Rates ¿From our linear factor model, it immediately follows that the log currency risk premium can be restated in terms of the conditional factor betas:

$$
\begin{aligned}
\operatorname{crp}_{t+1}^{i} & \simeq b_{1} \operatorname{Cov}_{t}\left(\Delta c_{t+1}, \Delta e_{t+1}^{i}-\Delta p_{t+1}\right)+b_{2} \operatorname{Cov}_{t}\left(\Delta d_{t+1}, \Delta e_{t+1}^{i}-\Delta p_{t+1}\right) \\
& +b_{3} \operatorname{Cov}_{t}\left(r_{t+1}^{m}, \Delta e_{t+1}^{i}-\Delta p_{t+1}\right)
\end{aligned}
$$


This equation uncovers the key mechanism that explains the forward premium puzzle. We recall that, in the data, the risk premium $\left(\operatorname{crp} p_{t+1}^{i}\right)$ is positively correlated with foreign interest rates $R_{t}^{i, £}$ : low interest rate currencies earn negative risk premia and high interest rate currencies earn positive risk premia. To match these facts, in the simplest case of the $C C A P M$, the following necessary condition needs to be satisfied by the conditional consumption covariances:

$$
\begin{gathered}
\operatorname{Cov}_{t}\left(\Delta c_{t+1}, \Delta e_{t+1}^{i}\right) \text { small/negative when } R_{t}^{i, £} \text { is low, } \\
\operatorname{Cov}_{t}\left(\Delta c_{t+1}, \Delta e_{t+1}^{i}\right) \text { large/positive when } R_{t}^{i, £} \text { is high. }
\end{gathered}
$$

The same condition applies to durable consumption growth $\Delta d_{t+1}$ and the market return $r_{t+1}^{w}$ in our benchmark, three-factor model. This is exactly what we see in the consumption betas of currency, reported in figure (3). Both in the time-series (comparing the bar in the left panels and the right panels) and in the cross-section (going from portfolio 1 to 7), low foreign interest rates mean small/negative consumption betas. On the one hand, currencies that appreciate on average when US consumption growth is high and depreciate when US consumption growth is low, earn positive conditional risk premia. On the other hand, currencies that appreciate when US consumption growth is low and depreciate when it is high, earn negative risk premia. These currencies provide a hedge for US investors. Given the pattern of excess return variation across different currency portfolios, the covariance of changes in the exchange rate with US consumption growth term needs to switch signs over time for a given currency, depending on the portfolio it has been allocated to (or, its interest rate).

There is a substantial amount of time variation in the consumption betas of currencies. This reflects the time variation in interest rates and expected returns within each portfolio over time. Yet, most of our results can be understood in terms of the average consumption betas: on average, high interest rate currencies expose US investors to more consumption growth risk, while low interest rate currencies provide a hedge. The next subsection explains where these betas come from and why they are correlated with 
interest rates.

\section{B Where Do Consumption Betas of Currencies Come from?}

The answer is time-variation in the conditional distribution of the foreign stochastic discount factor $m^{i}$. Investing in foreign currency is like betting on the difference between your own and your neighbor's intertemporal marginal rate of substitution (IMRS). These bets are very risky if your IMRS is not correlated with your neighbor's, but they provide a hedge when her IMRS is highly correlated and more volatile. We identify two potential mechanisms to explain the consumption betas of currencies. Low foreign interest rates either signal (1) an increase in the volatility of the foreign stochastic discount factors or (2) an increase in the correlation of the foreign stochastic discount factor with the domestic one.

To obtain these results, we assume that markets are complete and that the SDF are log-normal. Essentially, we re-interpret an existing derivation by Backus, Foresi and Telmer (2001), and we explore its empirical implications.

Currency Risk premia and the SDF In the case of complete markets, investing in foreign currency amounts to shorting a claim that pays off your SDF and going long in a claim that pays off the foreign SDF. The net payoff of this bet depends on the correlation and volatility of these SDFs. Assuming that the inflation betas are small enough and that markets are complete, the size of the log currency risk premium $c r p_{t+1}^{i}$ is given by ${ }^{15}$ :

$$
s t d_{t} m_{t+1}\left[s t d_{t} m_{t+1}-\operatorname{Corr}_{t}\left(m_{t+1}, m_{t+1}^{i}\right) s t d_{t} m_{t+1}^{i}\right]
$$

Its sign is determined by the standard deviation of the home SDF relative to the one of the foreign SDF scaled by the correlation between the two SDFs. What does this equation imply? Obviously, either a higher conditional volatility of the foreign SDF or

\footnotetext{
${ }^{15}$ See Appendix B for a proof.
} 
a higher correlation of the SDFs in the case of lower interest rate currencies -and the reverse for high interest rates- would generate the right pattern in risk premia.

Example In the case of the simple $C C A P M$, these two mechanisms can be stated in terms of the joint distribution of consumption growth at home and abroad. Assume that the stand-in agents in both countries share the same coefficient of relative risk aversion. Then, abstracting again from the inflation betas, the sign of the conditional risk premium is determined by:

$$
\left[s t d_{t}\left(\Delta c_{t+1}^{U S}\right)-\operatorname{Corr}_{t}\left(\Delta c_{t+1}^{U S}, \Delta c_{t+1}^{i}\right) s t d_{t}\left(\Delta c_{t+1}^{i}\right)\right]
$$

A low correlation of foreign consumption growth with US consumption growth for high interest rate currencies, and a high correlation for low interest rate currencies, creates the right variation in currency risk premia. More volatile consumption growth for low interest rate currencies also delivers this pattern. What is the economic intuition behind this mechanism?

In our benchmark representative agent model with complete markets, the foreign currency appreciates when foreign consumption growth is lower than US aggregate consumption growth and depreciates when it is higher. When markets are complete, the value of a dollar delivered tomorrow in each state of the world, in terms of dollars today, equals the value of a unit of foreign currency tomorrow delivered in the same state, in units of currency today: $Q_{t+1}^{i} / Q_{t}^{i}=M_{t+1}^{i} / M_{t+1}$, where the exchange rate $Q^{i}$ is in units of the US good per unit of the foreign good. Thus, in the case of a CRRA representative agent in the US, the percentage change in the real exchange rate equals the percentage change in consumption growth times the coefficient of risk aversion: $\Delta q_{t+1}^{i}=\gamma\left(\Delta c_{t+1}-\Delta c_{t+1}^{i}\right)$.

If the foreign stand-in agent's consumption growth is strongly correlated with and more volatile than that of his US counterpart, his national currency provides a hedge for the US representative agent. For example, consider the case in which foreign consumption growth is twice as volatile as US consumption growth and perfectly correlated with 
US consumption growth. In this case, when consumption growth is -2 percent below the mean in the US, it is -4 percent below the mean abroad, and the real exchange rate appreciates by $\gamma$ times 2 percent. When consumption growth is +2 percent in the US, it is twice as high abroad ( +4 percent), and the real exchange rate depreciates by $\gamma$ times 2 percent. This currency is a perfect hedge against US aggregate consumption growth risk. Consequently, investing in this currency should provide a low excess return. Thus, for this heteroscedasticity mechanism to explain the pattern in currency excess returns, low interest rate currencies must have aggregate consumption growth processes that are conditionally more volatile than US aggregate consumption growth. This is in line with the theory. All else equals, in the case of power utility, an increase in the conditional volatility of aggregate consumption growth lowers the real interest rate. ${ }^{16}$ If real and nominal interest rates move in sync, a low nominal interest rate should predict a higher conditional volatility of aggregate consumption growth. Of course, if inflation is very high and volatile, the nominal and the real interest rates effectively are detached, and this mechanism would disappear, as it seems to in the data.

Time-variation in the correlation between the domestic and the foreign SDF is the second mechanism. In the previous example, if the consumption growth of a high interest rate country is perfectly negatively correlated with US consumption growth, then a negative consumption shock of 2 percent in the US leads to a depreciation of the foreign currency by $\gamma$ times 2 percent. This currency depreciates when US consumption growth is low. Consequently, investing in this currency should provide a high excess return. Thus, for this correlation mechanism to explain the pattern in currency excess returns, the correlation between domestic and foreign consumption growth should decrease with the interest rate differential. Empirically, we find strong evidence to support that mechanism: foreign consumption growth is less correlated with US consumption growth when the foreign interest rate is high.

Evidence The heteroscedasticity mechanism is also at the heart of the habit-based model of the exchange rate risk premium in Verdelhan (2005). In his model, the do-

\footnotetext{
${ }^{16}$ This can be shown by starting from the Euler definition of the real risk-free rate and by assuming that aggregate consumption growth is log-normal.
} 
mestic investor receives a positive exchange rate risk premium in times when he is more risk-averse than his foreign counterpart. Times of high risk-aversion correspond to low interest rates. Thus, the domestic investor receives a positive risk premium when interest rates are lower at home than abroad.

Test of the Correlation Mechanism In addition, we document some direct evidence in the data for the correlation mechanism. For data reasons, we focus on non-durable consumption growth only. Using a sample of ten developed countries, we regressed a country's non-durable consumption growth on US non-durable consumption growth and US consumption growth interacted with the lagged interest rate differential:

$$
\Delta c_{t+1}^{i}=\alpha_{0}+\alpha_{1} \Delta c_{t+1}^{U S}+\alpha_{2}\left(R_{t}^{i, £}-R_{t}^{\$}\right) \Delta c_{t+1}^{U S}+\epsilon_{t+1}
$$

The results obtained over the post-Bretton Woods period on annual data are reported in table 9 . The coefficients on the interaction terms $\alpha_{2}$ are negative for all countries, except for Japan. The table also reports ninety percent confidence intervals for these interaction coefficients. They show that the $\alpha_{2}$ coefficients are significantly negative for 7 countries. The last row of each panel reports the pooled time series regression results. The ninety percent confidence interval includes only negative coefficients.

As is clear from the $\alpha_{2}$ estimates in column 3, the conditional correlation between foreign and US annual consumption growth decreases with the interest rate gap for all countries except Japan. We also found the same pattern for Japanese and UK consumption growth processes (not reported).

\section{Robustness}

This section goes through a number of robustness checks: (1) we look at other factor models, (2) we split up the sample, (3) we introduce other test assets, (4) we re-estimate the model on developed currency portfolios, and (5) we re-estimate the model using the Generalized Method of Moments. 
Table 9: Consumption Growth Regressions

\begin{tabular}{lccccc}
\hline \hline Country & $\alpha_{1}$ & $\alpha_{2}$ & $\underline{\alpha_{2}}$ & $\overline{\alpha_{2}}$ & $R^{2}$ \\
\hline AUS & 0.071 & -0.06 & -0.086 & -0.033 & 0.13 \\
$C A N$ & 0.58 & -0.095 & -0.15 & -0.039 & 0.26 \\
$F R$ & 0.27 & -0.0058 & -0.092 & 0.081 & 0.056 \\
GER & -0.24 & -0.064 & -0.16 & 0.029 & 0.013 \\
$I T A$ & 0.26 & -0.06 & -0.098 & -0.022 & 0.072 \\
$J A P$ & 0.71 & 0.072 & 0.003 & 0.14 & 0.26 \\
NE & 0.21 & -0.11 & -0.17 & -0.057 & 0.15 \\
$S W E$ & 0.59 & -0.24 & -0.39 & -0.089 & 0.18 \\
$S W I$ & -0.39 & -0.07 & -0.1 & -0.037 & 0.19 \\
UK & 0.74 & -0.1 & -0.15 & -0.052 & 0.21 \\
pooled & 0.27 & -0.047 & -0.088 & -0.007 & 0.038 \\
\hline \hline
\end{tabular}

Notes: This table reports the results for the following regression: $\Delta c_{t+1}^{i}=\alpha_{0}+\alpha_{1} \Delta c_{t+1}^{U S}+\alpha_{2}\left(R_{t}^{i, £}-R_{t}^{\$}\right) \Delta c_{t+1}^{U S}+\epsilon_{t+1}$. The last row reports the results from a pooled time series regression. The sample is 1971-2002 and the data is annual (for the Netherlands the sample is 1978-2002 and for Switzerland 1981-2002). We used the optimal lag length to estimate the spectral density matrix (Andrews, 1991). $\alpha_{2}$ and $\overline{\alpha_{2}}$ are respectively one standard error below and above the point estimate $\alpha_{2}$.

\section{A Factor Models}

The Capital Asset Pricing Model (CAPM), due to Sharpe (1964) and Treynor (1961) is a useful benchmark. In this model, the excess return on the US total market portfolio is the only asset pricing factor. We use the CRSP value-weighted excess return, denoted $R^{w}$, as a proxy for the market return:

$$
\frac{M_{t+1}}{E\left[M_{t+1}\right]} \simeq 1-b_{w} R_{t+1}^{w}
$$

Of course, the same decomposition of the risk premium in market price of risk (here $\left.\lambda_{w}\right)$ and betas $\left(\beta_{w}\right)$ applies here. The model implies that the market price of risk $\lambda_{w}$ equals the expected excess return on the market, because the market has a beta of one.

In addition, we consider the bond and equity factor models developed by Fama and French (1992). Fama and French (1992) add the return on a portfolio that goes long in small and short in big firms $\left(R_{t+1}^{S M B}\right)$ and the return on a portfolio that goes long in high book-to-market and short in low book-to-market stocks $\left(R_{t+1}^{H M L}\right)$ as additional equity 
pricing factors. ${ }^{17}$ For bond pricing, they use the slope of the yield curve $\left(R_{t+1}^{\text {long }}\right)$ and the default spread on corporate bonds $\left(R_{t+1}^{c o r p}\right)$. These factors proxy for the underlying undiversifiable macroeconomic risk (Fama and French (1993)).

Table 10 lists the results for the CAPM and the Fama-French factor models. We start with the CAPM in the first column. The price of market risk $\lambda_{w}$ is estimated to be around 7 percent. This number is in line with the theory, which prescribes a market price of risk of seven percent, the average excess return on the market. However, the CAPM explains only 4 percent of the variation in returns over the entire sample. Introducing the Fama-French bond and equity factors does not improve the pricing much. The FamaFrench equity factors explain 8 percent, while the bond factors explain 20 percent. The mean absolute pricing error does not drop below 200 basis points for any of these models, compared to 32 basis points for the EZ-DCAPM. The pricing errors for the first and the seventh portfolio are large, in excess of 100 basis points, in all three cases. The factor models, which work in equity and bond markets, break down in currency markets.

Clearly, the currency excess returns are not spanned by Fama-French equity or bond factors. This makes currency portfolios particularly useful as test assets. Daniel and Titman (2005) argue that even factors which are loosely correlated with $H M L$ and $S M B$ will appear successful in explaining the cross-section of asset returns, but our currency returns are not correlated with these. In fact, our currency portfolios are out-of-sample test assets, as advocated by Lewellen, Nagel and Shanken (2006).

\section{B Post-Bretton-Woods}

While the same investor Euler equation applies to fixed and floating regimes, the joint distribution of consumption growth and foreign currency returns is affected by a change in the exchange rate regime, and this may affect the estimation. To address this, we split the sample.

\footnotetext{
${ }^{17} S M B$ means small-minus-big and $H M L$ means high-minus-low.
} 
Table 10: Estimation of Linear Factor Models with 8 Currency Portfolios Sorted on Interest Rates

\begin{tabular}{lccc}
\hline \hline Factor Price & CAPM & FF-equity & FF-bonds \\
\hline Market & 7.921 & 5.718 & \\
& {$[9.873]$} & {$[10.569]$} & \\
SMB & & 3.504 & \\
& & {$[5.782]$} & \\
HML & & -7.264 & \\
& & {$[6.892]$} & \\
slope & & & 9.125 \\
& & & {$[6.446]$} \\
default & & & -2.645 \\
& & & {$[3.170]$} \\
\hline Stats & & & \\
\hline MAE & 2.374 & 2.266 & 2.001 \\
$R^{2}$ & 0.044 & 0.088 & 0.194 \\
$p-$ value & {$[0.000]$} & {$[0.000]$} & {$[0.000]$} \\
\hline \hline
\end{tabular}

Notes: This table reports the Fama-MacBeth estimates of the factor prices (in percentage points) using 8 annually rebalanced currency portfolios as test assets. The sample is 1953-2002 (annual data). The standard errors are reported between brackets. The last three rows report the mean absolute pricing error (in percentage points), the $R^{2}$ and the p-value for a $\chi^{2}$ test.

Consumption-CAPM The results for the 1971-2002 sub-sample are reported in Table 11. Panel A reports the Consumption-CAPM estimates, and Panel B reports the factor model estimates. The estimated price of consumption growth risk is 2.4 percent in the benchmark model, and it is still significant, while the price of durable consumption growth risk is around 3 percent. The implied coefficient of risk aversion is 98 , close to our earlier estimate of 114. Our benchmark model, the EZ-DCAPM explains 65 percent of the variation over this sub-sample, and the mean absolute pricing error increases to 128 basis points, substantially higher than the number for the entire sample. Even though all four models pass the $\chi^{2}$-test, only the models with durable consumption growth as factor explain a large fraction of the cross-sectional variation in returns.

Factor Models The results for the factor models are shown in the second panel of Table 11. In this sub-sample, the $C A P M$ explains none of the variation and the Fama- 
Table 11: Estimation of Linear Factor Models with 8 Currency Portfolios Sorted on Interest Rates

\begin{tabular}{|c|c|c|c|c|}
\hline \multicolumn{5}{|c|}{ Panel A: Consumption Models } \\
\hline & CCAPM & DCAPM & EZ-CCAPM & EZ-DCAPM \\
\hline \multirow[t]{2}{*}{ Nondurables } & 1.705 & 1.617 & 2.496 & 2.422 \\
\hline & {$[1.087]$} & {$[1.095]$} & {$[0.914]$} & {$[0.914]$} \\
\hline \multirow[t]{2}{*}{ Durables } & & 2.556 & & 2.916 \\
\hline & & {$[0.959]$} & & {$[0.905]$} \\
\hline \multirow[t]{2}{*}{ Market } & & & 15.260 & 8.481 \\
\hline & & & {$[7.804]$} & {$[7.259]$} \\
\hline$M A E$ & 2.647 & 1.661 & 2.283 & 1.283 \\
\hline$R^{2}$ & 0.259 & 0.535 & 0.361 & 0.641 \\
\hline$p-$ value & {$[0.312]$} & {$[0.535]$} & {$[0.222]$} & {$[0.479]$} \\
\hline \multicolumn{5}{|c|}{ Panel B: Factor Models } \\
\hline \multirow{3}{*}{ Market } & CAPM & FF-equity & FF-bonds & \\
\hline & 1.943 & 5.174 & & \\
\hline & {$[8.443]$} & {$[8.684]$} & & \\
\hline \multirow[t]{2}{*}{$S M B$} & & 9.530 & & \\
\hline & & {$[5.188]$} & & \\
\hline \multirow[t]{2}{*}{$H M L$} & & -6.525 & & \\
\hline & & {$[5.965]$} & & \\
\hline \multirow[t]{2}{*}{ slope } & & & 3.967 & \\
\hline & & & [9.628] & \\
\hline \multirow[t]{2}{*}{ default } & & & 0.661 & \\
\hline & & & [2.393] & \\
\hline$M A E$ & 3.549 & 2.905 & 3.457 & \\
\hline$R^{2}$ & 0.006 & 0.186 & 0.032 & \\
\hline$p-$ value & {$[0.001]$} & {$[0.001]$} & {$[0.001]$} & \\
\hline
\end{tabular}

Notes: This table reports the Fama-MacBeth estimates of the factor prices (in percentage points) using 8 annually rebalanced currency portfolios as test assets. The sample is 1971-2002 (annual data). The standard errors are reported between brackets. The factors are demeaned. The last three rows report the mean absolute pricing error (in percentage points), the $R^{2}$ and the p-value for a $\chi^{2}$ test.

French factor models explain less than 18 percent of the variation in returns. The mean absolute pricing error does not decrease below 290 basis points. The price of market risk is not significantly different from zero in any of the models. None of these factor models pass the $\chi^{2}$-test. 


\section{Other Test Assets}

As an additional test of the statistical significance of our results, we examine whether the compensation for aggregate risk in currency markets differs from that in domestic equity markets from the perspective of a US investor. To do so, we add 5 bond portfolios and the 6 Fama-French benchmark stock portfolios, as test assets.

We start by adding only equity as test assets. These Fama-French portfolios sort stocks according to size and book-to-market, because both size and book-to-market predict returns. This leaves us with 14 sample moment conditions. We want to find out if these returns can be priced by the same SDF that prices currency risk. By adding these to the currency portfolios, we do an out-of-sample test, as is clear from figure 4. The filled dots represent the currency portfolios, and the actual excess returns are on the vertical axis. The currency portfolios have radically different returns that are not correlated with stock returns.

The first column in Table 12 reports the results obtained using only currency portfolios as test assets. The second column (E/C) reports the results for equity and currency portfolios. Nondurable consumption risk is priced higher in equity markets (about 200 basis points), while durable consumption risk is priced about the same. The estimated price of nondurable consumption growth risk is 3.8 percent obtained from all 14 test assets, compared to the 2.2 estimate for currency only and 4.2 for equity only. The price of durable consumption growth risk is 4.3 percent for equity and currency, compared to 4.7 percent for currency and 3.8 percent for equity only. The implied risk aversion coefficient estimates are substantially higher.

Then we add bond and equity returns to the test assets to obtain a total of 19 moment conditions. The bond portfolios (CRSP Fama bond portfolios) contain bonds with maturities between 1 and 2 years, 2 and 3 years, 3 and 4 years, 4 and 5 years, 5 and 6 years. In the last column $(\mathrm{E} / \mathrm{B} / \mathrm{C})$, we report that the price of consumption risk is now around 2.4 percent, closer to the currency market estimate, and the durable consumption factor price is much smaller, closer to 2 percent. But, in spite of these large differences in factor prices, the implied risk aversion estimates when bonds are included, 


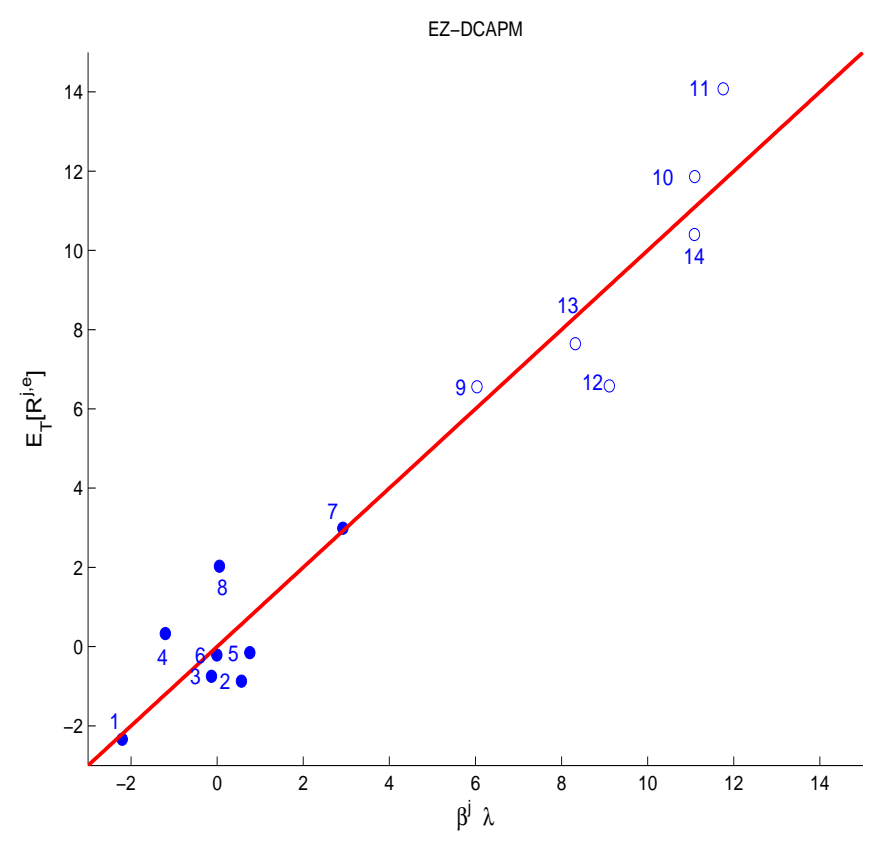

Figure 4: $E Z-D C A P M$.

This figure plots the actual vs. the predicted excess returns for 8 currency portfolios. The predicted excess returns are on the horizontal axis. The Fama-MacBeth estimates are obtained using 8 currency portfolios and the 6 Fama-French equity benchmark portfolios (sorted on size and book-to-market) as test assets (see Table 12). The filled dots (1-8) represent the currency portfolios. The empty dots (9-14) represent the equity portfolios. The data are annual and the sample is 1953-2002.

are very close to the currency-only ones, around 115 .

\section{Developed Currencies}

To guard against the possibility that our results are due to sovereign risk instead of currency risk, we exclude developing countries from the sample. The portfolio returns are much noisier and the Sharpe ratios are smaller, simply because we only have 20 developed countries in the sample. In addition, the cross-sectional variation in interest rates is now dominated by the time series variation in the average interest rate difference with the US. That is why we use the interest rate difference with the US as an instrument when testing the US investor's Euler equation, as we did in section II.D. The first column in Table 13 shows the estimates obtained using the average interest rate difference with the US as an instrument; the second column shows the results obtained using the interest 
Table 12: Estimation of Linear Factor Models with 8 Currency Portfolios sorted on Interest Rates, 6 Equity Portfolios sorted on Size and Book to Market and 5 Bond Portfolios

\begin{tabular}{|c|c|c|c|c|c|}
\hline & $\mathrm{C}$ & $\mathrm{E}$ & $\mathrm{E} / \mathrm{C}$ & $\mathrm{E} / \mathrm{B}$ & $\mathrm{E} / \mathrm{B} / \mathrm{C}$ \\
\hline \multicolumn{6}{|l|}{ Factor Price } \\
\hline \multirow[t]{2}{*}{ Nondurables } & 2.194 & 4.276 & 3.757 & 2.467 & 2.445 \\
\hline & {$[0.830]$} & {$[0.945]$} & {$[0.567]$} & {$[0.786]$} & {$[0.507]$} \\
\hline \multirow[t]{2}{*}{ Durables } & 4.696 & 3.788 & 4.294 & 1.889 & 2.047 \\
\hline & {$[0.968]$} & {$[1.227]$} & {$[0.785]$} & {$[1.300]$} & {$[0.875]$} \\
\hline \multirow[t]{2}{*}{ Market } & 3.331 & 23.292 & 13.992 & 9.730 & 10.787 \\
\hline & {$[7.586]$} & {$[8.658]$} & {$[2.846]$} & {$[2.667]$} & {$[2.804]$} \\
\hline \multicolumn{6}{|l|}{ Parameters } \\
\hline \multirow[t]{2}{*}{$\gamma$} & 113.375 & 200.652 & 180.428 & 115.317 & 114.682 \\
\hline & {$[5.558]$} & [6.389] & {$[3.904]$} & {$[5.536]$} & [3.568] \\
\hline \multirow[t]{2}{*}{$\sigma$} & 0.210 & -0.028 & -0.028 & -0.004 & -0.011 \\
\hline & {$[0.056]$} & {$[0.002]$} & {$[0.001]$} & {$[0.002]$} & {$[0.002]$} \\
\hline \multirow[t]{2}{*}{$\alpha$} & 1.146 & 0.118 & 0.311 & -0.062 & 0.030 \\
\hline & {$[0.001]$} & {$[0.020]$} & {$[0.010]$} & {$[0.038]$} & {$[0.029]$} \\
\hline \multicolumn{6}{|l|}{ Stats } \\
\hline$M A E$ & 0.325 & 1.263 & 1.657 & 1.283 & 1.992 \\
\hline$R^{2}$ & 0.869 & 0.842 & 0.937 & 0.939 & 0.905 \\
\hline$p$-value & 0.628 & 0.353 & 0.002 & 0.000 & 0.000 \\
\hline
\end{tabular}

Notes: This table reports the Fama-MacBeth estimates of the factor prices (in percentage points) using 8 annually rebalanced currency portfolios, 6 Fama-French benchmark portfolios sorted on size and book-to-market and 5 Fama bond portfolios (CRSP) as test assets. The sample is 1953-2002 (annual data). The standard errors are reported between brackets. The factors are demeaned. The last three rows report the mean absolute pricing error (in percentage points), the $R^{2}$ and the p-value for a $\chi^{2}$ test.

rate difference with the $i$-th portfolios as an instrument. The consumption factor prices are positive and significant, but somewhat lower than those obtained on the entire sample of currencies. As a result, the implied risk aversion estimates are lower as well. Consumption risk explains between 63 and $88 \%$ of the variation in managed currency portfolio returns for the subset of developed currencies. 
Table 13: Estimation of Linear Factor Models with 8 Managed Developed Currency Portfolios sorted on Interest Rates

\begin{tabular}{lcc}
\hline \hline & Average $\Delta R$ & $\Delta R^{i}$ \\
\hline Factor Price & & \\
\hline Nondurables & 1.311 & 1.551 \\
Durables & {$[0.688]$} & {$[0.707]$} \\
& 2.456 & 2.201 \\
Market & {$[0.955]$} & {$[1.032]$} \\
& -22.155 & -12.221 \\
& {$[12.539]$} & {$[10.937]$} \\
\hline Parameters & & \\
\hline$\gamma$ & 61.781 & 66.712 \\
& {$[4.999]$} & {$[5.227]$} \\
$\sigma$ & 0.305 & 0.122 \\
& {$[0.011]$} & {$[0.009]$} \\
$\alpha$ & 0.629 & 0.408 \\
& {$[0.186]$} & {$[0.159]$} \\
\hline Stats & & \\
\hline$R^{2}$ & 0.630 & 0.885 \\
$p-$ value & 0.073 & 0.015 \\
\hline \hline
\end{tabular}

Notes: This table reports the Fama-MacBeth estimates of the factor prices (in percentage points) using 8 annually rebalanced managed developed currency portfolios as test assets. The sample is 1971-2002 (annual data). In column 1, we use the mean interest rate difference on portfolios 1-7 as an instrument. In column 2, we use the interest rate difference on portfolio $i$ as the instrument for the $i$-th moment. The standard errors are reported between brackets. The factors are demeaned. The last two rows report the $R^{2}$ and the p-value for a $\chi^{2}$ test.

\section{E GMM}

We also estimated the linear factor model using the general method of moments (GMM, Hansen (1982)). The moment conditions are the sample analog of the population pricing errors. In the first stage of the estimation procedure, we use the identity matrix as the weighting matrix, $W=I$, while in the second stage we use $W=S^{-1}$ where $S$ is the covariance matrix of the pricing errors in the first stage. Since we focus on linear factor models, GMM is equivalent to a 2-stage linear regression of the average excess returns $E_{T}\left(R_{t}^{e}\right)$ on the factor-return moments $E_{T}\left(R f_{t}^{\prime}\right)$.

The estimation results are reported in Panel A of Table 14. The first column looks at 
the estimates obtained using only currency portfolios as test assets. Columns 2-5 report the results for other test assets. The model cannot be rejected for any combination of test assets.

In the currency only case (column 1), the GMM factor price estimates for nondurable and durable consumption are significant at the 5 percent level. The price of nondurable consumption risk is 2.4 percent, compared to 2.2 percent using Fama-MacBeth - and the price of durable consumption risk is 3.5 percent, compared to 4.7 percent. The $E Z$-DCAPM passes the J-test at 5 percent significance level; the p-value reports the probability of observing these pricing errors if the model is true. The measures of fit we obtain are worse than before, because, in the case of linear factor models, GMM is equivalent to running a regression of average returns on the cross-moment of returns and factor without a constant in the regression.

The Fama-MacBeth procedure uses factor betas that were estimated in the first step of the procedure, and the standard errors reported in Table 5 do not correct for this. However, in the currency only case, the GMM standard errors are quite close to the 'uncorrected' standard errors.

In Panel B of table 14, we report the Shanken (1992)-corrected standard errors for the Fama-MacBeth coefficients in parentheses. These include a correction for the sampling error due to the estimation of the betas. We also report the standard errors generated by bootstrapping 10.000 times from the empirical distribution of returns and factors in \{\} . Clearly, the Shanken standard errors tend to be much larger than the GMM standard errors as well as the bootstrapped standard errors, especially when the number of test assets is small. The large differences with the bootstrapped errors suggest this may be due to the small sample properties of the Shanken correction. In addition, the derivation of these Shanken-corrected standard errors assumes the errors are i.i.d; Jagannathan and Wang (1998) show that the uncorrected Fama-MacBeth standard errors do not necessarily overstate the precision of the factor price estimates in the presence of conditional heteroskedasticity. 


\section{Related Literature}

Our paper draws on at least two strands of the exchange rate literature. First, there is a large literature on the efficiency of foreign exchange markets. Interest rate differentials are not unbiased predictors of subsequent exchange rate changes. In fact, high interest rate differentials seem to lead to further appreciations on average. This is known as the forward premium puzzle. Fama (1984) argues that time-varying-risk premia can explain these findings only if (1) risk premia are more volatile than expected future exchange rate changes, and (2) risk premia are negatively correlated with the size of the expected depreciation. Many authors have concluded that this sets the bar too high, and they have ruled out risk-based explanations.

Other authors have pursued the risk premium explanation. Our paper is closest to Hollifield and Yaron (2001), Harvey, Solnik and Zhou (2002) and Sarkissian (2003). Hollifield and Yaron (2001) find some evidence that real factors, not nominal ones, drive most of the predictable variation in currency risk premia. Using a latent factor technique on a sample of international bonds, Harvey et al. (2002) find empirical evidence of a factor premium that is related to foreign exchange risk. Sarkissian (2003) finds that the cross-sectional variance of consumption growth across countries helps explain currency risk premia, but he focuses on unconditional moments of currency risk premia on a currency-by-currency basis, while we find that most of the variation depends on the level of the foreign interest rate. Finally, Backus et al. (2001) show that, in a general class of affine models, explaining the forward premium puzzle requires the state variables to have asymmetric effects on the state prices in different currencies. We reinterpret their results in our framework.

There is another literature that relates the volatility and persistence of real exchange rates to aggregate consumption. Standard, dynamic equilibrium models, imply a strong link between consumption ratios and the real exchange rate, but, as Backus and Smith (1993) point out, there is no obvious link in the data. This lack of correlation motivates the work by Alvarez, Atkeson and Kehoe (2002). They generate volatile, persistent real exchange rates in a Baumol-Tobin model with endogenously segmented markets, 
effectively severing the link between changes in the real exchange rate and aggregate consumption growth. Our results suggest that this may be too radical a remedy. Conditional on the interest rate, there appears to be a strong link between consumption growth and exchange rates.

Finally, our results provide guidance for applied theoretical work in this area. A good theory of real exchange rates needs to explain why (nominal) interest rates line up with a currency's aggregate consumption growth betas. And it must explain why this relation breaks down for very high interest rates. At least on the first count, our results provide empirical support for work by Verdelhan (2005). He replicates the forward discount bias in a model with external habits and he provides estimates to support this mechanism.

\section{Conclusion}

Aggregate consumption growth risk explains a large fraction of the average changes in the exchange rate, conditional on foreign interest rates. On average, high interest rate currencies depreciate when US consumption growth is low and US investors want to be compensated for this risk. Thus, aggregate consumption growth risk is key to understanding exchange rates. Thus far real exchange rates appeared to be unrelated to aggregate consumption in the data (e.g. Backus and Smith (1993) and Chari, Kehoe and McGrattan (2002)), but our results suggest that the correlation between changes in the real exchange rate and consumption growth varies strongly over time and across currencies. 
Table 14: Estimation of Linear Factor Models with 8 Currency Portfolios sorted on Interest Rates, 6 Equity Portfolios sorted on Size and Book to Market and 5 Bond Portfolios

\begin{tabular}{|c|c|c|c|c|c|}
\hline & $\mathrm{C}$ & $\mathrm{E}$ & $\mathrm{E} / \mathrm{C}$ & $\mathrm{E} / \mathrm{B}$ & $\mathrm{E} / \mathrm{B} / \mathrm{C}$ \\
\hline \multicolumn{6}{|l|}{ Factor Price } \\
\hline \multicolumn{6}{|c|}{ Panel A: GMM } \\
\hline \multirow[t]{2}{*}{ Nondurables } & 2.372 & 2.732 & 2.537 & 0.822 & 2.006 \\
\hline & {$[0.846]$} & {$[1.192]$} & {$[0.723]$} & {$[0.877]$} & {$[0.486]$} \\
\hline \multirow[t]{2}{*}{ Durables } & 3.476 & 2.573 & 2.699 & -0.562 & 1.386 \\
\hline & {$[1.204]$} & {$[1.942]$} & {$[0.985]$} & {$[1.418]$} & {$[0.662]$} \\
\hline \multirow[t]{2}{*}{ Market } & 10.204 & 12.216 & 13.238 & 8.380 & 9.566 \\
\hline & {$[7.868]$} & {$[5.869]$} & {$[4.075]$} & {$[6.072]$} & {$[3.472]$} \\
\hline \multicolumn{6}{|l|}{ Stats } \\
\hline$M A E$ & 1.170 & 1.384 & 1.400 & 1.128 & 1.286 \\
\hline$p$-value & 0.068 & 0.629 & 0.781 & 0.795 & 0.409 \\
\hline \multicolumn{6}{|c|}{ Panel B: FMB } \\
\hline \multirow[t]{4}{*}{ Nondurables } & 2.194 & 4.276 & 3.757 & 2.467 & 2.445 \\
\hline & {$[0.830]$} & {$[0.945]$} & {$[0.567]$} & {$[0.786]$} & {$[0.507]$} \\
\hline & $(2.154)$ & $(3.059)$ & $(1.656)$ & $(1.574)$ & $(1.025)$ \\
\hline & $\{1.343\}$ & $\{3.725\}$ & $\{1.143\}$ & $\{1.496\}$ & $\{0.926\}$ \\
\hline \multirow[t]{4}{*}{ Durables } & 4.696 & 3.788 & 4.294 & 1.889 & 2.047 \\
\hline & [0.968] & {$[1.227]$} & {$[0.785]$} & {$[1.300]$} & {$[0.875]$} \\
\hline & $(2.518)$ & $(3.973)$ & $(2.292)$ & $(2.595)$ & $(1.756)$ \\
\hline & $\{1.716\}$ & $\{4.449\}$ & $\{1.758\}$ & $\{2.579\}$ & $\{1.445\}$ \\
\hline \multirow[t]{4}{*}{ Market } & 3.331 & 23.292 & 13.992 & 9.730 & 10.787 \\
\hline & {$[7.586]$} & {$[8.658]$} & {$[2.846]$} & {$[2.667]$} & {$[2.804]$} \\
\hline & $(19.754)$ & $(28.057)$ & $(8.613)$ & $(5.857)$ & (6.092) \\
\hline & $\{11.182\}$ & $\{27.202\}$ & $\{3.395\}$ & $\{3.300\}$ & $\{2.998\}$ \\
\hline \multicolumn{6}{|l|}{ Stats } \\
\hline$M A E$ & 0.325 & 1.263 & 1.657 & 1.283 & 1.992 \\
\hline$p-$ value & 0.628 & 0.353 & 0.002 & 0.000 & 0.000 \\
\hline
\end{tabular}

Notes: Panel A reports the 2-stage GMM estimates of the factor prices (in percentage points) using 8 annually re-balanced currency portfolios, 6 Fama-French benchmark portfolios sorted on size and book-to-market and 5 Fama bond portfolios (CRSP) as test assets. The sample is 1953-2002 (annual data). In the first stage, we use the identity matrix as the weighting matrix. In the second stage we use the optimal weighting matrix (no lags). The sample is 1953-2002 (annual data). The standard errors are reported between brackets. The factors are demeaned. The pricing errors correspond to the first stage estimates. Panel B reports the Fama-MacBeth estimates of the factor prices (in percentage points) using 8 annually re-balanced currency portfolios, 6 Fama-French benchmark portfolios sorted on size and book-to-market and 5 Fama bond portfolios (CRSP) as test assets. The sample is 1953-2002 (annual data). The standard errors are reported between brackets. The standard errors in parentheses include the Shanken correction. The standard errors in \{\} are generated by bootstrapping 10.000 times. The factors are demeaned. The last two rows report the mean absolute pricing error (in percentage points) and the p-value for a $\chi^{2}$ test. 43 


\section{References}

Alvarez, Fernando, Andrew Atkeson, and Patrick J. Kehoe, "Money, Interest Rates and Exchange Rates with Endogenously Segmented Markets," Journal of Political Economy, 2002, 110(1), 73-112.

Andrews, Donald W.K., "Heteroskedasticity and Autocorrelation Consistent Covariance Matrix Estimation," Econometrica, 1991, 59 (1), 817-858.

Backus, David and Gregor Smith, "Consumption and Real Exchange Rates in Dynamic Economies with Non-Traded Goods," Journal of International Economics, 1993, 35, 297-316.

, Silverio Foresi, and Chris Telmer, "Affine Models of Currency Pricing: Accounting for the Forward Premium Anomaly," Journal of Finance, 2001, 56.

Bansal, Ravi and Magnus Dahlquist, "The Forward Premium Puzzle: Different Tales from Developed and Emerging Economies," Journal of International Economics, 2000, 51, 115-144.

Breeden, Douglas T., "An Intertemporal Asset Pricing Model with Stochastic Consumption and Investment Opportunities," Journal of Financial Economics, 1979, 7, 265-296.

Campbell, J. Y., "Asset Prices, Consumption and the Business Cycle," in John Taylor and Mark Woodford, eds., Handbook of Macroeconomics, Amsterdam: North Holland, 1999.

Chari, V.V., Patrick Kehoe, and Ellen McGrattan, "Can Sticky Price Models Generate Volatile and Persistent Real Exchange Rates?," The Review of Economic Studies, 2002, 69, 533-564.

Cochrane, John H., Asset Pricing, Princeton, N.J.: Princeton University Press, 2001.

Daniel, Kent and Sheridan Titman, "Testing Factor-Model Explanations of Market Anomalies," 2005. 
Dunn, K. and K. Singleton, "Modeling the Term Structure of Interest Rates Under Nonseparable Utility and Durability of Goods," Journal of Financial Economics, 1986, 17, 769-799.

Eichenbaum, Martin and Lars Peter Hansen, "Estimating Models with Intertemporal Substitution Using Aggregate Time Series Data," Journal of Business and Economic Statistics, 1990, 8 (1), 53-69.

Epstein, L. G. and S. Zin, "Substitution, Risk Aversion and the Temporal Behavior of Consumption and Asset Returns: A Theoretical Framework," Econometrica, 1989, $57,937-969$.

Fama, Eugene F., Foundations of Finance: Portfolio Decisions and Securities Prices, Basic Books, 1976.

, "Forward and Spot Exchange Rates," Journal of Monetary Economics, 1984, 14, $319-338$.

and James D. MacBeth, "Risk, Return, and Equilibrium: Empirical Tests," The Journal of Political Economy, 3 1973, 81, 607-636.

and Kenneth R. French, "The Cross-Section of Expected Stock Returns," Journal of Finance, 1992, $4^{7}$ (2), 427-465.

and __ , "Common Risk Factors in the Returns on Stocks and Bonds," Journal of Financial Economics, 1993, 33, 3-56.

Hansen, Lars Peter, "Large Sample Properties of Generalized Method of Moments Estimators," Econometrica, 1982, 50, 1029-54.

and R. Jagannathan, "Implications of Security Markets Data for Models of Dynamic Economies," Journal of Policitical Economy, 1991, 99, 252-262.

and Robert J. Hodrick, "Forward Exchange Rates as Optimal Predictors of Future Spot Rates: An Econometric Analysis," Journal of Political Economy, 1980, $88,829-853$. 
Harvey, Campbell R., Bruno Solnik, and Guofu Zhou, "What Determines Expected International Asset Returns?," Annals of Economics and Finance, 2002, 3, 249-298.

Hodrick, Robert, The Empirical Evidence on the Efficiency of Forward and Futures Foreign Exchange Markets, Chur, Switzerland: Harwood Academic Publishers, 1987.

Hollifield, Burton and Amir Yaron, "The Foreign Exchange Risk Premium: Real and Nominal Factors," 2001. Working Paper Wharton School, University of Pennsylvania.

Jagannathan, Ravi and Zhenyu Wang, "The Conditional CAPM and the CrossSection of Expected Returns," The Journal of Finance, March 1996, 51 (1), 3-53. and _ _ "An Asymptotic Theory for Estimating Beta-Pricing Models Using Cross-Sectional Regressions," Journal of Finance, 1998, 53, 1285-1309.

Lewellen, Jonathan, Stefan Nagel, and Jay Shanken, "A Skeptical Appraisal of Asset-Pricing Tests," NBER Working Paper, 2006, 12360.

Lewis, Karen K., "Puzzles in International Financial Markets," in G. Grossman and K. Rogoff, eds., Handbook of International Economics, Amsterdam: Elsevier Science B.V., 1995, pp. 1913-1971.

Lucas, Robert E., "Asset Prices in an Exchange Economy," Econometrica, 1978, 46 (6), 1429-54.

Meese, Richard A. and Kenneth Rogoff, "Empirical Exchange Rate Models of the Seventies: Do They Fit Out of Sample?," Journal of International Economics, $1983,14,3-24$.

Mehra, R. and E. C. Prescott, "The Equity Premium: A Puzzle," Journal of Monetary Economics, 1985, 15., 145-161. 
Quinn, Dennis, "The Correlates of Changes in International Finance Regulation," American Political Science Review, 1997, 91(3).

Reinhart, Carmen, Kenneth Rogoff, and Miguel A. Savastano, "Debt Intolerance," Brookings Papers on Economic Activity, 2003, 1, 1-74.

Sarkissian, Sergei, "Incomplete Consumption Risk Sharing and Currency Risk Premiums," Review of Financial Studies, 2003, 16, 983-1005.

Service, Global Credit Research Moody's Investors, "Sovereign Bond Defaults, Rating Transitions, And Recoveries (1985-2002)," Global Credit Research, 2003, February.

Shanken, Jay, "On the Estimation of Beta-Pricing Models," The Review of Financial Studies, 1992, 5 (2), 1-33.

Sharpe, William, "Capital Asset Prices: A Theory of Market Equilibrium under Conditions of Risk," Journal of Finance, 1964, 19(3), 425-442.

Singh, Manmohan, "Recovery Rates from Distressed Debt - Empirical Evidence from Chapter 11 Filings, International Litigation, and Recent Sovereign Debt Restructurings," IMF Working Paper WP/03/161, 2003, August.

Treynor, Jack, "Towards a Theory of Market Value of Risky Assets," Unpublished Manuscript, 1961.

Verdelhan, Adrien, "A Habit Based Explanation of the Exchange Rate Risk Premium," 2005. Working Paper Boston University.

Yogo, Motohiro, "A Consumption-Based Explanation of Expected Stock Returns," Journal of Finance, 2006, 61(2). 


\section{Appendix A Data}

\section{Appendix A1 Panel}

Our panel includes 81 countries. We include each of the following countries for the dates noted in parenthesis: Angola (2001-2002), Australia (1953-2002), Austria (1960-1991), Belgium (1953-2002), Bangladesh (1984-2001), Bulgaria (1992-2002), Bahrain (1987-2002), Bolivia (1994-2002), Brazil (1996-2002), Barbados (1966-2002), Botswana (1996-2002), Canada (1953-2002), Switzerland (1980-2002), Chile (1997-2002), China (2002-2002), Colombia (19982002), Costa-Rica (2000-2002), Cyprus (1975-2002), Czech Republic (1996-2000), Germany (1953-2002), Denmark (1976-2002), Egypt (1991-2002), Spain (1985-2002), France (1960-2002), United Kingdom (1953-2002), Ghana (1978-2002), Greece (1985-2002), Hong-Kong (19912002), Honduras (1998-2001), Croatia (2000-2002), Hungary (1988-2002), India (1993-2002), Ireland (1969-2002), Iceland (1987-2002), Israel (1995-2002), Italy (1953-2002), Jamaica (19532002), Japan (1960-2002), Kenya (1997-2002), Kuwait (1979-2002), Kazakhstan (1994-2002), Lebanon (1977-2002), Sri Lanka (1982-2002), Lithuania (1994-2001), Latvia (1994-2002), Mexico (1978-2002), Macedonia (1997-2002), Malta (1987-2002), Mauritius (1996-2002), Malaysia (1961-2002), Namibia (1991-2002), Nigeria (n.a), Netherlands (1953-2002), Norway (19842002), Nepal (1982-2002), New-Zealand (1978-2002), Pakistan (1997-2002), Philippines (19762002), Poland (1992-2002), Portugal (1985-2002), Romania (1994-2002), Russian Federation (1994-2002), Singapore (1987-2002), El Salvador (2001-2002), Slovak Republic (1993-2002), Slovenia (1998-2002), Sweden (1955-2002), Swaziland (1981-2002), Thailand (1997-2002), Trinidad and Tobago (1964-2002), Tunisia (1990-2002), Turkey (1985-2002), Taiwan (1974-2002), Uruguay (1992-2002), United States (1953-2002), Venezuela (1996-2002), Vietnam (1997-2002), Serbia and Montenegro (2002-2002), South Africa (1988-2002), Zambia (1978-2002), Zimbabwe (19622002). The exchange and T-bill rates were downloaded from Global Financial Data. The maturity of the T-bill rates is 3 months, except for Costa-Rica and Poland (both 6 months). The time period for each country is determined by data availability and openness of the financial market (according to Quinn (1997)'s index, see below).

Developed Countries Our panel of developed countries includes 20 countries. We include each of the following countries for the dates noted in parenthesis: Australia (1953-2002), Austria (1960-1991), Belgium (1953-2002), Canada (1953-2002), Switzerland (1980-2002), Germany (1953-2002), Denmark (1976-2002), Spain (1985-2002), France (1960-2002), United Kingdom (1953-2002), Greece (1985-2002), Ireland (1969-2002), Italy (1953-2002), Japan (19602002), the Netherlands (1953-2002), Norway (1984-2002), New-Zealand (1978-2002), Portugal (1985-2002), Sweden (1955-2002), United States (1953-2002). 


\section{Appendix A2 Recovery Rates}

First, Moody's research studies twenty-four defaulted sovereign bonds issued by seven countries. They compute the average of the face value thirty days after default. They obtain a recovery rate of thirty-four percent on an issue-based computation (and forty-one percent on an issuer-based one). These figures are biased downward as they do not include the Peruvian and Venezuelan cases. Second, Singh (2003) computes the recovery rate as the ratio of post-restructuring prices on average post-default prices. The sample considers seven debt restructuring events for four sovereigns (Ukraine, Ecuador, Russia and Ivory Coast). The author finds that the average debt work-out period is two years and the weighted average recovery rate is one hundred and fifteen percent. This figure might still be biased downwards as bond prices continued to rise after the two-year window. We have assumed a recovery rate of seventy percent.

\section{Appendix A3 Financial Data and Macroeconomic Factors}

Returns We obtained the Fama-French factors and the 25 book-to-market portfolios for the US from Kenneth French's web site at http://mba.tuck.dartmouth.edu/pages/faculty/ken.french/index.html. The 6 CRSP Fama bond portfolios are downloadable from http://wrds.wharton.upenn.edu.

International Consumption Data The international consumption data (see Campbell (1999)) were downloaded from John Campbell's web site at http://kuznets.fas.harvard.edu/campbell/data.html. We have updated the data set using Datastream and IFS series along John Campbell's guidelines. We use per capita consumption deflated by that country's CPI.

Real Per Household Consumption Growth We define real nondurable and services consumption (NDS), as nondurable consumption deflated by the NIPA nondurable price index plus services deflated by the NIPA services price index minus housing services deflated by the NIPA housing services price index minus clothes and shoes deflated by the NIPA clothes and shoes price index. The basis of all NIPA price deflators is $1996=100$. They are not the same as the corresponding CPI components from the BLS. Per household variables are obtained by dividing by the number of households. 


\section{Appendix B Proofs}

Linear factor Model If we take logs of equation (2) and we approximate around $\rho=1$, we obtain the following expression for the log of the stochastic discount factor:

$$
-m_{t} \approx-\kappa \log \beta+b_{1} \Delta c_{t}+b_{2} \Delta d_{t}+b_{3} r_{w, t}
$$

where the factor loadings depend on the preference parameters as in equation (4). We can back out the structural parameters from the factor loading estimates, as follows: $\sigma=(1-$ $\left.b_{3}\right) /\left(b_{1}+b_{3}\right), \gamma=b_{1}+b_{2}+b_{3}$ and $\alpha=b_{2} / b_{1}+b_{2}+\left(b_{3}-1\right) / \rho$.

As is standard, the non-linear SDF can be approximated as a function of the log SDF $m$ :

$$
\frac{M_{t}}{E\left[M_{t}\right]} \simeq 1+m_{t}-E\left[m_{t}\right]
$$

¿From equation (11), this implies that the SDF is linear in the factors.

$$
-\frac{M_{t}}{E\left[M_{t}\right]} \simeq k+b_{1} \Delta c_{t}+b_{2} \Delta d_{t}+b_{3} r_{t}^{w}
$$

More generally, if the SDF is linear in the factors: $\frac{M_{t}}{E\left[M_{t}\right]}=k+b^{\prime} f_{t}$, then the unconditional Euler equation can be restated as follows: $E\left[R^{i, e}\right]=b^{\prime} \Sigma_{f i}$ where $\Sigma_{f i}=E\left(f_{t}-\mu_{f}\right)\left(R^{e, i}\right)$. The expected excess return is the factor loading times risk. The linear factor model can be stated as a beta pricing model:

$$
E\left[R^{i, e}\right]=\lambda^{\prime} \beta_{i}
$$

where $\lambda=\Sigma_{f f} b$ is the factor risk premium and $\Sigma_{f f}=E\left(f_{t}-\mu_{f}\right)\left(f_{t}-\mu_{f}\right)^{\prime}$.

Similarly, starting from the conditional Euler equation $E_{t}\left[M_{t+1} R_{t+1}^{e, i}\right]=0$, and approximating the SDF around its conditional mean: $-\frac{M_{t+1}}{E_{t}\left[M_{t+1}\right]}=k_{t-1}+b^{\prime} f_{t}$, the conditional excess return on asset $i$ can be stated as:

$$
E_{t}\left[R_{t+1}^{e, i}\right]=\sum_{k} b_{k} \operatorname{cov}_{t}\left(f_{t+1}^{k} R_{t+1}^{e, i}\right) .
$$

Log Currency Risk Premium We assume that the pricing kernel and portfolio returns are conditionally log-normal. Returns are priced using:

$$
E_{t} m_{t+1} R_{t+1}^{i}=1 \text {. }
$$

Hence,

$$
\log E_{t} m_{t+1} R_{t+1}^{i}=0,
$$


and, with log-normality

$$
\log E_{t} m_{t+1} R_{t+1}^{i}=E_{t}\left(\log m_{t+1}+r_{t+1}^{i}\right)+\frac{1}{2} \operatorname{Var}_{t}\left(\log m_{t+1}+r_{t+1}^{i}\right)=0
$$

This implies that the Euler equation can be restated as:

$$
E_{t} m_{t+1}+E_{t} r_{t+1}^{i}+\frac{1}{2}\left[\operatorname{Var}_{t} m_{t+1}+\operatorname{Var}_{t} r_{t+1}^{i}\right]+\operatorname{Cov}_{t}\left(m_{t+1}, r_{t+1}^{i}\right)=0 .
$$

Let $R_{t}^{f}$ be the risk free rate between period $t$ and $t+1$, known at $t$, then $r_{t}^{f}=-\log E_{t} m_{t+1}$. Since $\log E_{t} m_{t+1}=E_{t} m_{t+1}+\frac{1}{2} \operatorname{Var}_{t} m_{t+1}$ and likewise for $R_{t+1}^{i}$, we get:

$$
\log E_{t} R_{t+1}^{i}-r_{t}^{f}=-\operatorname{Cov}_{t}\left(m_{t+1}, r_{t+1}^{i}\right) .
$$

We know that:

$$
r_{t+1}^{i}=r_{t}^{i, £}+\Delta e_{t+1}^{i}-\Delta p_{t+1},
$$

where $e_{t}^{i}$ is the exchange rate between the currency of country $i$ and the dollar. The log currency risk premium is then equal to:

$$
\log \left(\operatorname{crp}_{t+1}^{i}\right)=-\operatorname{Cov}_{t}\left(m_{t+1}, \Delta e_{t+1}^{i}\right)+\operatorname{Cov}_{t}\left(m_{t+1}, \Delta p_{t+1}\right) .
$$

Complete markets If markets are complete, then the percentage change in the real exchange rate is $\Delta \log q_{t+1}^{i}=\log m_{t+1}^{i}-\log m_{t+1}$. Substituting this in the expression for the $\log$ currency risk premium,

$$
\log \left(\operatorname{crp}_{t+1}^{i}\right)=-\operatorname{Cov}_{t}\left(\log m_{t+1}, \Delta \log e_{t+1}^{i}-\Delta \log p_{t+1}\right),
$$

and assuming that $\operatorname{Cov}_{t}\left(\log m_{t+1}, \Delta \log p_{t+1}^{i}\right)=0$, produces the following expression for the log currency risk premium:

$$
\log \left(\operatorname{crp}_{t+1}^{i}\right)=-\operatorname{Cov}_{t}\left(\log m_{t+1}, \log m_{t+1}^{i}-\log m_{t+1}\right) .
$$

This immediately delivers equation (9). 